\title{
Köyceğiz-Dalyan Özel Çevre Koruma Bölgesi’ndeki Anadolu sığla ormanlarında yarasa (Chiroptera) aktivitesinin belirlenmesi
}

Determination of the bat (Chiroptera) activity in the Anatolian sweetgum forests inside Köyceğiz-Dalyan Specially Protected Area

\author{
Okan ÜRKER ${ }^{1}$ \\ Tarkan YORULMAZ ${ }^{2}$
}

\footnotetext{
' Cankırı Karatekin Üniversitesi, Eldivan Sağlık Hizmetleri Meslek Yüksek Okulu, Çankır1

${ }^{2}$ Çankırı Karatekin Üniversitesi, Fen Fakültesi, Çankırı
}

\begin{abstract}
Sorumlu yazar (Corresponding author) Okan ÜRKER

okan.urker@gmail.com
\end{abstract}

Geliş tarihi (Received)

26.11.2019

Kabul Tarihi (Accepted)

31.01 .2020

Atuf (To cite this article): URKER, O, YORULMAZ, T . (2020). Köyceğiz-Dalyan Özel Cevre Koruma Bölgesi'ndeki Anadolu sığla ormanlarında yarasa (Chiroptera) aktivitesinin belirlenmesi. Ormancılık Araștırma Dergisi , 7 (1), 88-103. DOI: https://doi.org/10.17568/ogmoad.651223

\section{Öz}

Türkiye yarasalarının ormanlarımızdaki varlığı, aktivitesi ve orman için ne ifade ettiğine dair çalışmalar yok denecek kadar azdır. Pek çok canlı için barınma, korunma, beslenme ve üreme ortamı olan orman ekosistemi, yarasalar için de kimi zaman tüneme ve barınma yeri iken kimi zamanda beslenme alanlarıdır. Bu çalışma ile yarasaların orman ekosistemlerindeki varlığ ve çeşitliliği ele alınmıştır. Bu kapsamda Muğla ilinde Köyceğiz-Dalyan Özel Çevre Koruma Bölgesi sınırlarında yer alan Anadolu sığla ormanları içerisindeki yarasa tür çeşitliliği, tür zenginliği ve aktivite yoğunluğu analiz edilmiştir. Temmuz 2017-Temmuz 2019 dönemleri arasını kapsayan bu çalışma süresince 30 ha ile 250 hektar genişlikleri arasında değişen 10 farklı Anadolu sığla ormanı parçasında ampirik gözlemlerin yanı sıra ağ kurulumu, atrap kullanımı, 18 adet yarasa kutusu yerleştirimi, 1 adet manuel ve 2 adet full-spektrum yarasa dedektörü (toplamda 67 gün1978 adet ses kaydı) kullanımı metot olarak tercih edilmiştir. Tüm bu çalışmaların sonucunda toplamda 11 yarasa türünün varlığ sığla ormanlarında ve yakın çevresindeki bağlantılı habitatlarda kaydedilmiş olup bu türlerden Myotis daubentonii, Myotis emarginatus, Pipistrellus nathusii, Pipistrellus pygmaeus, Plecotus macrobullaris bölge için ilk kez kaydedilmiştir.

Anahtar kelimeler: Sığla ormanı, yarasa, orman yarasaları, yarasa ekolojisi, yarasa kutusu, doğa koruma

\begin{abstract}
There are almost a few studies that focus on the importance of forests for the bat species in Turkey. The forest ecosystem is sometimes roosting, sheltering and feeding environment for bats as well as the other species. In this study, diversity, richness, abundance and activity density of the bats within the borders of Köyceğiz-Dalyan Specially Protected Area in Muğla Province of Turkey were analyzed. During this study, which performed between July 2017 and July 2019, the empirical observations in 10 different Anatolian sweetgum forests ranging from 30 hectares to 250 ha, as well as mist-net installation, use of sweep-net, 18 bat boxes (house) placement, use of 1 manual and 2 full-spectrum bat detectors (67 days in total-1978 voice records) was preferred as a method. As a result of the study, presence of 11 bat species in total was recorded in the Anatolian sweetgum forests and related habitats in the surrounding area. Myotis daubentonii, Myotis emarginatus, Pipistrellus nathusii, Pipistrellus pygmaeus, Plecotus macrobullaris species were recorded for the first time in the Southwestern Anatolia within this study.
\end{abstract}

Keywords: Sweetgum forest, bats, forest bats, bat ecology, bat box, nature conservation 


\section{Giriş}

Günümüzde dünyada 5490 memeli türünün yay1lış gösterdiği bilinmektedir. Memelilerin içinde 32 familya ve yaklaşı 2300 türü ile kemiricilerin en kalabalık takımı oluşturduğu bilinmektedir. Memeli sınıfının tür bakımından zengin ikinci takımı ise 18 familya, 197 cins ve yaklaşı 1300 türü ile yarasalardır (Merrit, 2010; Richardson, 2011; Bogdanowicz ve ark., 2014). Hayvanlar (Animalia) âlemine ait Memeli (Mammalia) sınıfı içindeki gerçek uçuş özelliği gösteren tek takım olması itibariyle de diğer memelilerden bariz biçimde ayrılmaktadır (Albayrak, 2000).

Kutup bölgeleri hariç dünyanın hemen hemen her yüzeyinde gözlenebilen yarasalar 1lıman bölgeler ve tropiklerde tür çeşitliliği açısından zirve noktasına ulaşmaktadır. Ana besin kaynakları açısından böcekler ile beslenenleri Microchiroptera, meyve ile beslenenleri ise Megachiroptera takımları altında toplanır. Yarasaların bununla birlikte kuş, amfibi, küçük memeli, hayvan kanı ve diğer yarasalar ile de beslenebildiği bilinmektedir (Dietz ve ark., 2009). Yarasalar genellikle türler arasında farklılık gösteren çok özel barınma ihtiyaçlarına sahip canlılardır. Mağaralar, yarıklar, ağaçlar, kütük altları ve hatta insanların yaşadığı binalarda bile tüneyebilmektedirler. Bu özelliklerine aktif uçuş kabiliyetleri ve ekolokasyon özellikleri de eklendiğinde dünyadaki yarasa türlerinin çok geniş bir habitat tercihi olduğu anlaşılmaktadır.

Türkiye'de biri Megachiroptera 38'i Microchiroptera altordosuna ait 39 tür yayılış gösterdiği literatür verilerinden bilinmektedir (Albayrak ve Aşan, 1999; Aşan ve Baydemir, 2014; Yorulmaz ve Arslan 2016). Yarasalar beslenmek, tünemek ve üremek için farklı habitat ve yapıları kullanabilmektedir.

Bugüne kadar Türkiye'de yarasalarla ilgili yapılan çalışmalarda daha çok mağara yarasaları üzerine odaklanılmıştır. Türkiye yarasalarının ormanlarımızdaki varlığı, aktivitesi ve orman için ne ifade ettiğine dair çalışmalar ise yok denecek kadar azdır. Pek çok canlı için barınma, korunma, beslenme ve üreme ortamı olan orman ekosistemi, yarasalar için de kimi zaman tüneme ve barınma yeri iken kimi zaman da beslenme alanları olarak karşımıza çıkmaktadır. Orman içinde yaşayan böcekler ise yarasalar için önemli bir besin kaynağ olup böcekler ile yarasaların aktivasyon dönemleri arasında doğrudan bir ilişki de söz konusudur. Orman içinde bulunan yaşlı ve kovuğa sahip ağaçlar pek çok yarasanın tünemesi için ideal ortamlar sağlamaktadır (Yorulmaz ve ark., 2018).

Anadolu sığla ormanları, yalnızca Güneybatı Ana- dolu ve Rodos Adası'nda doğal yayılış gösteren, günümüzde insan kaynaklı yoğun habitat parçalanması sonucu yok oluşun eşiğine gelmiş relikt - endemik bir orman ekosistemidir (Kavak ve Wilson, 2018). Bu ormanların subasar orman karakterinde olması, sürekli zemininde su barındırması, kışlar1 1lik yazları nemli bir mikroklima sunmasından dolayı yarasaların habitat tercihi açısından incelemeye değer bir yapı olarak ön plana çıkmaktadır.

$\mathrm{Bu}$ çalışma ile yarasaların orman ekosistemlerindeki varlığı ve çeşitliliği ele alınmaya çalışılmıştır. Bu kapsamda Muğla ili, Köyceğiz ve Ortaca ilçelerindeki Çevre ve Şehircilik Bakanlığı, Tabiat Varklıklarını Koruma Genel Müdürlüğü sorumluluk alanı olan Köyceğiz-Dalyan Özel Çevre Koruma Bölgesi sınırları dâhilinde yer alan Anadolu sığla ormanları içerisindeki yarasa tür çeşitliliği, tür zenginliği ve aktivite yoğunluğu analiz edilmiştir. Böylece örnek bir sığla ormanında yarasa varlığının ve çeşitliliğinin belirlenmesi, aktivitelerinin ve ormanı kullanma durumlarının tespit edilmesi amaçlanmıştır.

\subsection{Yarasaların ormanlar ile ekolojik ilişkisi}

Yarasalarla ormanlar arasında süreklilik arz eden ekolojik bir ilişkiden bahsedilebilir (Waldien ve Hayes, 2001). Yarasalar ormanları ağaçlarda tünemek, beslenmek ve avcılarından saklanmak amacıyla kullanmaktadır (Taylor, 2000). Tünekler yarasalar için kritik derecede öneme sahiptir. Yarasalar bu tünekleri kötü hava koşullarından ve potansiyel yırtıcılardan korunma, çiftleşme yeri, büyüme, kış uykusunu geçirme, besinleri sindirme ve diğer bireylerle sosyal olarak etkileşim kurma faaliyetlerinde yoğun olarak tercih etmektedir (Anthony ve Kunz, 1977).

Farklı vücut formundaki yarasalar, farklı hareket ve uçuş kabiliyetine sahiptir. Bu nedenle kullandıkları habitatlar da değişiklik göstermektedir. Örneğin, uzun kanatlı yarasalar hızlı olup daha uzaklara uçabilme kabiliyetine sahiptir. Bu nedenle sıklıkla orman katmanının üstünden beslenmeyi tercih etmektedir. Buna karşın, geniş kanatlı yarasalar ise yakın mesafeli uçarlar ve yüksek manevra kabiliyetine sahiptir. $\mathrm{Bu}$ nedenle orman zonu içerisindeki habitatlarda beslenebilir. Hiz ve manevra kabiliyeti yüksek olan uzun ve geniş kanatlı yarasalar ise orman içi açıklıklar, yollar ve orman sınırlarındaki habitatlarda beslenmeyi tercih edebilirler (Neuweiler, 1990).

Bazı araştırmacılar tüneme aktivitelerinin, yarasa topluluklarının çeşitliliğini etkilediğini (Jackson, 2015), oyukların tahrip edilmesi ile birlikte yarasa popülasyonlarında azalma olduğunu not etmiş- 
tir (Evelyn ve ark., 2004; Lunney ve ark., 1988). Tüneklerin gece-gündüz boyunca veya kış uykusu sırasında kullanılmasının yanı sıra yırtıcılardan ve çevresel faktörlerden korunmanın bir yolu olarak da tercih edildiği belirtilmiştir (O’Shea ve Bogan, 2003).

Buna ek olarak, beslenme alanı ile tüneme yeri arasındaki mesafenin kısaltılması amaciyla orman içinde beslenen pek çok yarasa türü de ağaçları tüneme amaçlı tercih etmektedir (Speakman ve Thomas, 2003). Yarasalar, ağaçların üzerindeki ağaç boşluklarını, ağaçkakan gibi kuşların açtıkları delikleri, doğal çürüme ile oluşan çatlakları, kısmen ayrılmış kabukların gevşek kabuk altlarını, yıldırım çarpması gibi doğal süreçlerle oluşabilen yarıkları tüneme amaciyla da kullanabilmektedir (Jackson, 2015).

Bununla beraber yarasalar yönlerini bulmak, avcılardan ve tehlikeli hava koşullarından korunmak için de ağaçları tercih edebilirler. Tüneme aktivitesinin sergilendiği ağaçların, ilgili orman zonundaki diğer ağaçlardan çok daha uzun boylu ağaçlar olduğu da sıklıkla gözlenmiştir (Brigham ve ark., 2002; Evelyn ve ark., 2004; Vonhof ve ark., 2004).

Türkiye'deki mevcut durum değerlendirildiğinde ülke sınırlarında kaydedilmiş 39 yarasa türünden 30'unun ormanı tünemek ya da avlanmak için kullandığı belirlenmiştir (Yorulmaz ve ark., 2016). Türkiye'deki yarasaların beslenme amacı ile özellikle çayırlar, sucul habitatlar ve ormanları tercih ettiği sıklıkla gözlenmektedir.

Orman alanları kendilerine özgü ekosistemleri ile yarasalar için barınak ve beslenme alanı olabilmektedir. Yarasalar, orman içinde var olan böcekleri besin olarak yoğun bir şekilde tercih edebilmektedir. Böylece orman içindeki zararlı böcek popülasyonlarının dengelenmesi söz konusu olmaktadır. Yarasalar genel bir alg1 olarak mağaralara bağımlı türler olarak bilinse de esasında çoğu yarasa türünün bütün yaşamı boyunca ormana bağımlı oldukları da bilinen başka bir gerçektir. Bu nedenle ormana bağımlı yarasaların korunması ve yönetiminin yaşam alanları olan ormanların sağlıklı bir yapı arz etmesine bağlı olduğu açık biçimde ortaya çıkmaktadır.

Türkiye yarasaları ormanları yoğun olarak beslenme habitatı olarak, daha az oranda da tüneme habitatı olarak tercih etme eğilimindedir. Türkiye ormanlarında yaşanan orman yangınları doğal risklerin başında gelirken yanlış ağaçlandırma, uygun olmayan ağaç kesimleri ve biyoçeşitliliği dikkate almayan amenajman planları, böcekler gibi orman zararlılarıla mücadelede kimyasal yöntemlerin tercih edilmesi ise orman alanlarının yönetimi noktasında yarasaların beslenmesi açısından ciddi riskler doğurabilmektedir. Öte yandan madencilik faaliyetleri ise antropojenik baskıların en büyüklerini teşkil etmekte ve habitat kaybı anlamında geri dönüşü mümkün olmayan kayıplar doğurmaktadır. Bunun yanı sıra son yıllarda artış gösteren "rüzgâr enerji santrali" kurma faaliyetleri ise yarasaların üzerinde stres koşulları doğurarak beslenme ve tüneme davranışlarında değişikliğe sebep olabilmektedir (Yorulmaz ve ark., 2018).

\subsection{Anadolu sığla ormanları}

Anadolu sığla ağacı (Liquidambar orientalis Miller) Türkiye'nin güneybatı bölümünde yayılış gösteren ve dünyada başka hiçbir yerde bulunmayan Doğu Akdeniz Havzası'na özgü kalıntı (relikt) endemik bir ağaç türüdür (Ürker ve Lise, 2018). Dere boylarında ve taban suyu yüksek alanlarda gruplar hâlinde veya tek tek görülen bu ağaç türünün sağlıklı orman oluşturabildiği bölgeler daha çok Muğla ilinin güneyindeki kıyı ilçeleri boyunca (Datça, Marmaris, Köyceğiz, Ortaca, Dalaman, Fethiye) gözlenmektedir (Ürker ve Çobanoğlu, 2017).

Anadolu sığla ormanlarının alanı 1949'da 6.312 ha iken 2014'te yaklaşık 2.000 hektara kadar düşmüştür (Özkil ve ark., 2017). Bu kalan orman varlığının yaklaşık \%60'l1k bölümü ise Köyceğiz-Dalyan Özel Çevre Koruma Bölgesi (ÖÇKB) sınırlarında bulunmaktadır (Ürker ve Çobanoğlu, 2017). Bu sebeple çalışma özelinde bu korunan alandaki orman yapısı inceleme alanı olarak seçilmiştir. Günümüzde neredeyse yok oluşun eşiğine gelmiş olan Anadolu sığla ağac1, bu özel durumu nedeniyle 2000 yılında IUCN Tehlike Kategorileri'ne göre hazırlanan listede, "Doğada Orta Vadeli Gelecekte Yüksek Tehdit Altında Olan Türler" kategorisinde yer almaktadır (Ekim ve ark., 2000).

Öte yandan, 2017 yılının sonundan bu yana, Anadolu sığla ağacı (Liquidambar orientalis), Dünya Doğayı Koruma Birliği (IUCN) tarafından küresel ölçekte türlerin tehdit durumunu sınıflayan Kırmızı Liste (Red List Ver. 2018.2) kategorilerinde 'korunmasiz-hassas (VU-Vulnerable)' olan mevcut statüsünden, bir üst derece olan 'tehdit altında (EN-Endangered)' statüsüne yükseltilmiştir (IUCN, 2019; Kavak ve Wilson, 2018). Yine bu özel durumu nedeniyle Anadolu sığla ağacı, 2001 yılında EUFORGEN tarafından "Değerli Yapraklılar" kategorisine alınarak Avrupa çapında korunacak bir tür olarak kabul edilmiştir (Alan ve Kaya, 2003).

Anadolu sığla ormanları genel olarak Anadolu'nun güneybatı bölümündeki kuzey doğudan güney batıya doğru giden bir hat üzerinde $0-1000$ m yükselti aralığındaki (optimum yükselti aralığı 0-400m'dir.) 
sulu dereler, vadiler, su özlerinin/pınarlarının yoğunlaştığ1 alanlar, subasar alanlar, nemli ve alüviyal düzlüklerde yoğunlaşmaktadır (Ürker ve Çobanoğlu, 2017). Ortalama 1000-1200 mm arası yağış alan ve yıllık ortalama sıcaklığ 1 15-20 derece aralığında olan yerleri seven Anadolu sığla ağaçlar1 düz-alçak nemli veya sslak yerlerde 'ova/taban günlüğü’, yamaçlardaki nispeten kuru yerlerde ise 'dağ günlüğü’ olarak adlandırılır. Sığla meşçereleri saf hâlde bulunabildiği gibi çınar, kızılçam, karaağaç, kızılağaç, dişbudak gibi meşçerelerle de karışabilir. Ağacın gelişiminde su, sıcaklık, yükseklik ve düz alüviyal arazi hep birlikte rol oynamaktadır. $\mathrm{Bu}$ faktörlerden biri eksik olduğu zaman Anadolu sığla ağacının gelişimi çok sınırlı olmaktadır. Buna rağmen birinci derecede önem arz eden faktörler s1caklık ve sudur. Arazinin eğimi daha çok yayılmay1 dolayısıyla orman oluşumunu önleyen bir faktör iken yükseklik ise gelişimi ve dağılımı kısıtlayan bir faktör olarak önem arz etmektedir (Kurt, 2008).

$\mathrm{Bu}$ ormanlardan elde edilen bir tür balzam-reçine olan sığla yağı, yüzyıllardır hem yöre halkının geçim kaynağ 1 ve temel sağlık ihtiyaçlarını karş1lamada önemli roller üstlenmiş hem de zaman zaman uluslararası ölçekte güçlü bir ekonomik ürün olmuştur. Öte yandan bu yağın elde ediliş aşamasında ortaya çıkan kabuk, sakız, günlük, buhur, tütsü gibi adlarla anılan yan ürünler de özellikle toplumların dini inanışlarında büyük bir yer tutarak ağaca ve ormana karşı manevi değerler yaratmıştır (Ürker ve Lise, 2018).

$\mathrm{Bu}$ ormanların ekonomik ve sosyo-kültürel önemlerinin yanı sıra ekolojik önemleri de büyük önem taşımaktadır. Özellikle subasar orman sistemine bağlı bünyesinde şekillenen eşsiz ekosistem ve biyolojik çeşitlilik özelliklerinin yanı sıra bölgedeki sel, taşkın benzeri doğal afetleri tamponlamadaki rolleri, yerel iklimin düzenlenmesi, erozyon kontrolü, zararlı böcek kontrolü ve havanın temizlenmesi gibi çeşitli ekosistem fonksiyonlarını yerine getirme açısından benzersiz ekolojik değerlere sahiptir. Yukarıda sıralanan değer ve önemlerinin aksine bu ormanlar, doğa tarihi açısından çok kısa denilebilecek -yaklaşık 100 yıllık- bir zaman diliminde trajik bir biçimde insan eliyle yok oluşun eşiğine getirilmiştir. Bu ormanların azalışına neden olan sorunların temelinde ise esasen Türkiye genelinde uygulanan kentleşme politikaları sonucunda verimli orman toprağının tarım toprağ olarak kullanılma gayesi yatmaktadır (Ürker ve Çobanoğlu, 2017).

Anadolu sığla ormanlarının bulunduğu verimli alüviyal toprağın narenciye üretim alanları olarak değerlendirilmesi yukarıda bahsi geçen bu politika ile uyumluluk arz etmektedir. Bu politika 1şığında şekillenen sorunları genel olarak özetlediğimizde ise mülkiyet problemleri, yerleşme ve tarla açma amaçlı işgaller, kesimler, yakmalar, drenaj ve sulama kanalları, otlatma baskısı, iklim değişikliği, kaçak-yanlış ve bilinçsiz sığla yağı üretimi gibi durumlarla karşılaşılmaktadır (Özkil ve ark., 2017).

Türkiye'de Anadolu sığla ormanları özelinde yarasaları konu edinen herhangi bir çalışma bugüne kadar yapılmamıştır. Ancak Köyceğiz ve yakın çevresinde yapılan biyolojik çeşitliliğin tespitine yönelik bazı çalışmalarda Rhinolophus ferrumequinum, Pipistrellus pipistrellus, Pipistrellus kuhlii türleri Fethiye, Köyceğiz, Sultaniye ve Dalyan'da kaydedilmiştir (Benda ve Horacek 1998; Baran ve ark., 1994; Albayrak, 2000). Bu türler daha çok yerleşim yerlerinde ve yakın çevrelerindeki tüneme noktalarında kaydedilmiştir. Yukarıda atıfları sunulan kaynaklar habitatlar özelinde irdelendiğinde bu bölgedeki orman içi habitatlara yönelik herhangi bir yarasa kaydı verilmediği de anlaşılmaktadir.

\subsection{Yarasa kutuları}

Yarasa kutuları, ahşap kuş yuvalarına benzer şekilde genellikle bir ağaç gövdesi, uzun bir direk veya bina gibi yüksek bir yapıya monte edilebilen ahşap kutulardır. Ancak kuş yuvalarının aksine, yarasa kutularının belirli kriterlere göre tasarlanması ve yerleştirilmesi gerekmektedir. Genel olarak yarasa kutuları, yarasalara sıcak, kuru ve güvenli bir tüneme alanı sağlamak için kullanılmaktadır. Yarasa kutuları, yarasalar için doğal tüneme yapıları ile aynı fırsatları sunmasa da, tüneme alanı çeşitliliğinin kısıtlı olduğu yerlerde tüneme habitatlarını artırmak için ideal bir seçenektir (Craig, 2015). Yarasa kutuları için literatürde ayrıca yarasa yuvaları terimi de kullanılabilmektedir.

Öte yandan, hem sivrisinekler ve diğer böceklere yönelik biyolojik mücadeledeki başarıları nedeniyle hem de doğa gözlemi açısından biyolojik çeşitliliği teşvik etmek amaciyla birçok insan da evlerinin bahçesine veya kendilerine ait yeşil alanlara yarasa kutularını yerleştirmek istemektedir. Bu tarz durumlarda genellikle yarasa kutuları, yapılan gözlemler ışığında yarasaların o alanı aktif olarak kullanmalarını müteakip yerleştirilmektedir (Kerth ve ark., 2001).

Yarasa kutuları, yırtıcılardan ve insan baskısından en iyi korumayı sağlayacak ağaçlara, direklere veya binalara monte edilmelidir. Uzun süreli güneş 1şığına ve suya maruz kalma problemine karşılık hem suya dayanıklı hem de güneş 1şığına dayanıklı iyi kalite ahşap veya taş binalar ideal seçimlerdir, binalarda saçak altındaki yerler de genellikle ba- 
şarılı sonuçlar vermektedir. Tüm yarasa kutuları genellikle yerden en az $3 \mathrm{~m}$ yükseğe monte edilmelidir; 4,5m ila $6 \mathrm{~m}$ yüksekliklerde daha iyi sonuçlar alınabilmektedir (Brittingham ve Williams, 2000).

Temel olarak odalı yarasa kutuları sedir veya kontrplak gibi suyu olabildiğince az geçiren malzemeden yapılmalı, dış yüzeyi iklimin soğuk olduğu bölgelerde koyu renkli ve daha 1lıman bölgelerde daha açık renkli olmalıdır. Sıcaklık, yarasa kutularının aktifliğine ve verimliliğine yönelik anahtar faktörlerden en önemlisidir. Maksimum Temmuz sıcaklığının $29^{\circ} \mathrm{C}$ 'nin altında olduğu bölgelerde yarasa kutularının dış yüzey rengi siyah veya koyu renkli olmalı iken ve $29{ }^{\circ} \mathrm{C}$ ila $35^{\circ} \mathrm{C}$ arasında olan alanlarda ise renk genellikle orta koyulukta bir kahverengi tonu olmalıdır (Tuttle ve ark., 2004).

Etkili bir yarasa kutusu (evi/yuvası) oluşturmak için dikkat edilmesi gereken ana konu başlıklar1; oda sayısı, biçim ve büyüklük olarak ön plana çıkmaktadır. Esasen günümüzde dünya üzerinde kullanılan birbirinden çok farklı tarzda yarasa kutusu modeli mevcuttur. Bu tasarımların başarısını etkileyen etmenlerden bazıları boyut, oda aral1ğ1, yüzey pürüzlülüğü, havalandırma delikleri, iniş zemini (pisti) olarak açıklanmaktadır (Craig, 2015). Öte yandan çalışılan konu özelinde (üreme kolonisi, tüneme, göç, dispersal, üreme, emzirme vb.) istenilen tasarıma karar verilirken maliyet, koloni büyüklüğü tercihi ve kutunun yerleştirileceği konum seçenekleri de yarasa kutusunun tasarımında özel olarak değişikliklerin yapılmasına sebep olabilmektedir.

Yarasa kutuları için dünya genelinde kullanılan en yaygın tasarımlar klasik yarasa kutuları (bat boxes), roket yarasa kutuları (rocket boxes), yarasa kulübeleri (mini condos, bat motels) ve levhalar (slabs) olarak bilinmektedir. Bunlardan bütün bir ağaç gövdesini veya bir direği çepeçevre saran roket kutular daha çok kolonilerin yerleşimi için tercih edilirken yarasa kulübeleri ise çok büyük sayılardaki yarasa popülasyonlarının grup oluşturabilmesi amacıyla yerleştirilmektedir. Ahşaptan veya metalden yapılmış tek parçalı levhalar ise daha çok binaların dış yüzeyinde tüneme amaçlı yapay kuru çatlak alanlar oluşturmak için tercih edilmektedir Craig, 2015).

Dünyada en sık kullanılan yarasa kutularından biri olan tek odacıklı yarasa kutuları ise ideal olarak en az $5 \mathrm{~cm}$ genişlik ve $5 \mathrm{~cm}$ yükseklikte odaya sa- hip olmalıdır. British Colombia'daki (Kanada) bazı gözlemler, tek odacıklı yarasa kutularının erkekler ya da steril dişiler tarafından daha sık kullanıldığını göstermiştir (Craig, 2015). Bu yarasa kutuları zaman zaman 50 yarasa bireyini barındıracak tüneme alanı sağlamaktadır. Çok odalı yarasa kutularının yaptığı sıcaklık gradyanını sunmadıkları için yavruların özellikle sicak dönemlerde bu tek oda içerisinde ölmesine neden olabilecek bir "yarasa tuzağı"na dönüşme riskleri de mevcuttur. Tek odacıklı yarasa kutularının yapımı daha basit, daha az maliyetli ve kurulumları daha basit olmakla birlikte çok odalı yarasa kutularının yarasalar için daha güvenli ve daha iyi tüneme imkânı sundukları da bilinmektedir.

\section{Materyal ve yöntem}

\subsection{Materyal}

\subsection{1. Çalışma alanı}

Muğla ili, Köyceğiz ve Ortaca ilçesi sınırlarında yer alan Köyceğiz-Dalyan ÖÇKB, tüm dünya üzerinde yayılış gösteren sığla ormanı varlığının yaklaşık \%60'lık bölümünü bünyesinde barındırması, sahip olduğu bu orman dokuları içerisinde de farklı parçalanma oranlarında ve ekolojik karakterlerdeki sığla orman toplulukları bulundurması nedeniyle çalışma alanı olarak belirlenmiştir (Özkil ve ark., 2017).

Köyceğiz-Dalyan ÖÇKB sınırlarında yayılış gösteren bu orman topluluğu içerisinden en küçüğü yaklaşık 30 hektar en büyüğü yaklaşık 250 hektar olan 10 farklı sığla ormanı parçası araştırma alanı olarak seçilmiştir (Şekil 1). Bu alan içinde farklı yaş aralığında ağaçlar ve su kaynaklarının bulunması, parçalanmış ve parçalanmamış ormanların yer alması, orman içlerinde ve kenarlarında tarım alanları ve/veya iskân alanlarının yer alıyor olması ve sahanın Özel Çevre Koruma Bölgesi gibi resmi bir koruma statüsüne sahip olması bu bölgenin araştırma alanı olarak tercih edilmesindeki kriterleri oluşturmaktadır. Çalışma sahası, Köyceğiz Gölü'nün çevresi boyunca yer alan orman dokularını kapsamakta olup batıda Hamitköy, güneybatıda Sultaniye ve Kersele Koyu, güneydoğuda Okçular, doğuda Tepearası ve Kavakarası, kuzeydoğuda Eski Köyceğiz ve Zeytinalanı, kuzeyde Yang1, kuzeybatıda ise Toparlar olmak üzere toplamda 10 farklı bölümden oluşmaktadır. Çalışma sahasının denizden yüksekliği (rakım) 0-25 metre arasında değişmektedir. 


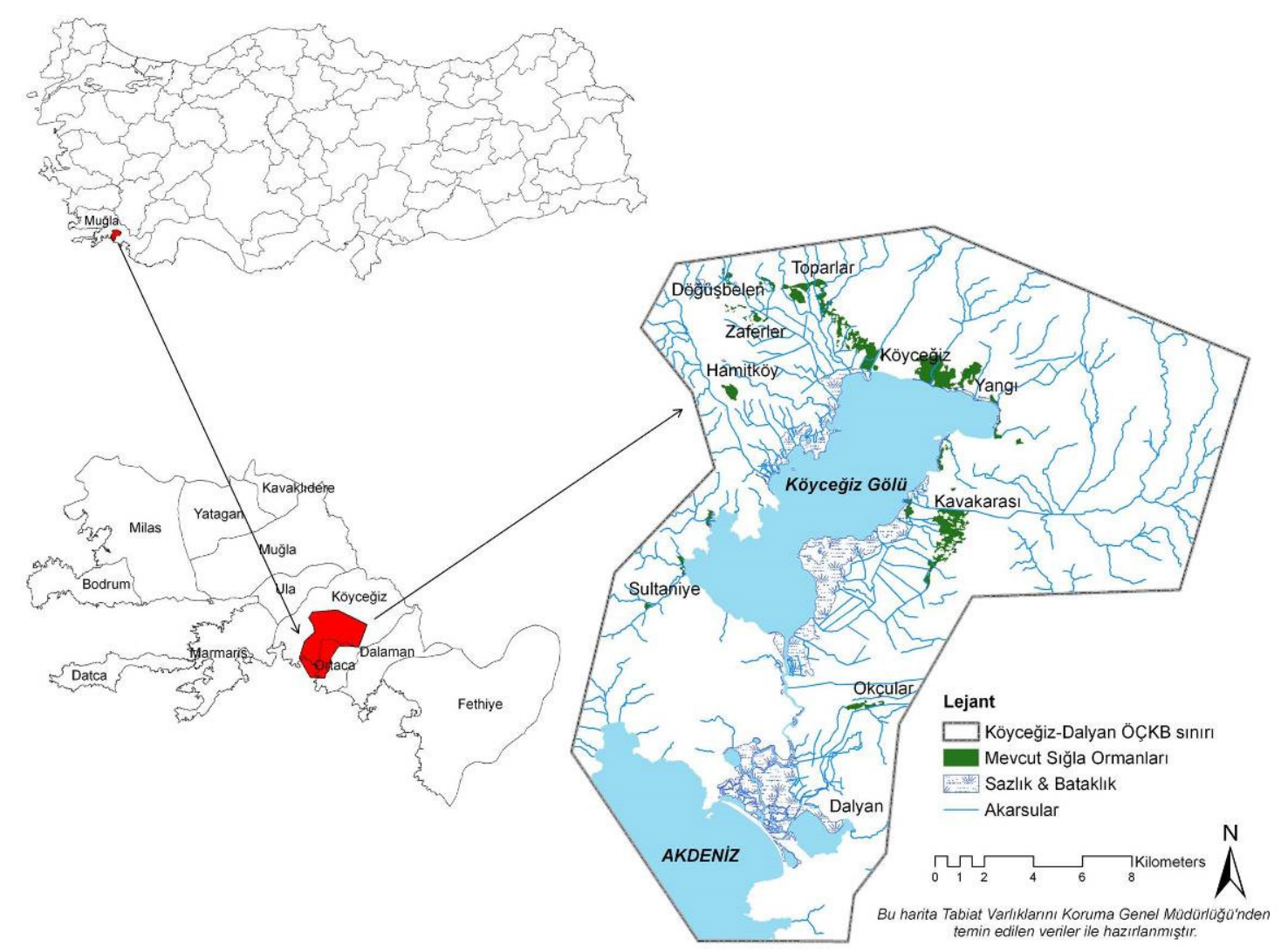

Şekil 1. Köyceğiz-Dalyan Özel Çevre Koruma Bölgesi’ne ait yer bulduru haritası.

Figure 1. Location map of Köyceğiz-Dalyan Specially Protected Area (SPA).

\subsection{2. Çalışmada kullanılan alet ve cihazlar}

Çalışma kapsamında sis ağları (ecotone mist net), atrap, eldivenler, el ve kafa lambaları, yarasa kutuları (18 adet) ve ultrasonik dedektör gibi alet ve cihazlar kullanılmıştır. Ultrasonik dedektör olarak bir adet manuel yarasa dedektörü (Batbox Baton) ve iki adet full spektrum yarasa dedektöründen (Ecoobs Batcorder 3.1, Pettersson D500X) yararlanılmıștır. Ses analizleri için MacOS ve Windows 8.1 işletim sistemine sahip bir bilgisayar kullanılmıştır. Batbox Baton cihazı 3,5 mm stereo ses bağlantı kablosu ile bilgisayara bağlanmıştır.

\subsection{Yöntem}

\subsubsection{Arazi çalışması}

\subsubsection{Orman içi yarasa aktivitesinin izlenmesi}

Orman içindeki yarasa aktivitesinin belirlenmesi amacı ile güneşin batışını müteakip tüneklerinden çıkarak beslenme aktivitesine başlayan yarasaların çalışma bölgelerindeki durumlarını (yoğunluk, aktif oldukları bölgeler, bulunan türler) dolaylı (müdahalesiz) yöntemlerle tespit edebilmek için özel olarak geliştirilmiş manuel veya full spektrum dedektörler/ses kayıt cihazları (ultrasonik ses tespiti ve kayıt cihazı) kullanılmıştır (Korner-Nievergelt ve ark., 2013, Correia ve ark., 2013).

Arazi çalışmalarında iki farklı tipte dedekör kullanılmıştır. Gün batımı ile birlikte tüneklerinden çıkarak beslenme aktivitesine başlayan yarasaların çalışma bölgelerindeki varlıklarını ve çeşitliliklerini tespit edebilmek için gün batımından önce belirlenen istasyonlara (çalıșma sahasını temsil edebilecek noktalar) kurulan gerçek zamanlı yarasa ses kayıt cihazı (16-150 kHz arası) gün batımından 30 dakika önce çalışmaya başlayarak sabahın ilk 1şıklarına kadar bölgeden geçen yarasa bireylerinin sesini, geçiş sıklıklarını ve geçiş saatini kaydetmek üzere ayarlanmıştır. Cihazın kurulumu esnasında mikrofonun zarar görmemesi (nemlenme, 1slanma, darbe) ve cihazın pil doluluk oranı gibi ayrıntılara dikkat edilmiştir. Gece boyunca kayıt yapan cihaz sabahın erken saatlerinde yerinden sökülerek kaydettiği ses dosyaları analiz edilmek üzere bilgisayara aktarılmıștır. Bu kapsamda Temmuz 2017 - Temmuz 2019 dönemi içerisinde toplamda 18 farklı noktada (farklı orman noktalarını temsil edecek şekilde) ilgili yarasa dedektörü kurularak 
alınan ses kayıtları analiz edilmiştir.

Ayrıca aynı dönemler içinde her çalışma alanını temsilen belli hatlar izlenerek gece boyunca manuel yarasa dedektörü (Batbox Baton) ile anlık yarasa aktiviteleri de tespit edilmiştir. Manuel olarak yarasa sesleri Batbox Baton cihazı (Frekans bölmeli dedektör (Frequency Division Detector) ile taranarak $(17 \mathrm{kHz}-120 \mathrm{kHz})$ anlık olarak bilgisayara aktarılmış ve BatScan9 programı aracılığıyla kaydedilmiştir. Kayıt esnasında görülen ses grafikleri (sonogram) daha sonra incelenerek yarasanın türü ve aktivite biçimi (beslenme, dolanım) tespit edilmiştir. Yarasa aktivitesinin arttığı bölgelerde daha uzun süre beklenerek (5-15 dakika) daha fazla veri elde edilmeye çalışılmıştır.

Manuel ve full-spektrum dedektörlerden elde edilen ses kayıtlarının teşhis ve tanımlanması için kullanılan ses analiz programlarında yazılımın hata payı, ses kalitesi gibi faktörler de göz önünde tutulduğunda, bu çalışma özelinde bir sesin hangi türe ait olduğuna ilişkin mutabakat sistemi için belirlenen oran \%95 olarak belirlenmiştir (Parsons ve Jones 2000; Russo ve Jones 2002; Rydell ve ark., 2002; Obrist ve ark., 2004). Öte yandan bu oranın altında kalmasına rağmen ses grafikleri incelenerek doğruluğundan emin olunan ses kayıtları da ayrıca değerlendirmeye dâhil edilmiştir.

\subsubsection{Orman içi yarasa varlığının tespit edilmesi}

Orman içinde faaliyet gösteren yarasaların doğrudan tespit edilmesi amaciyla Mart 2018 - Mart 2019 dönemi boyunca her çalışma bölgesini temsil edecek şekilde uygun görülen noktalara yani yarasaların orman içi beslenme koridorlarına, orman içi su kaynaklarına yakın geçiş yapabilecekleri koridorlara, mağara veya maden ocağı ağılarına vb. sis ağları gerilerek yarasalar canlı olarak yakalan-

Tablo 1. Dedektör ve diğer gözlemlere ait kayıt bilgileri.

Table 1. Information on the detectors, place and date of records.

\begin{tabular}{|c|c|c|}
\hline Dedektör/Gözlem Tipi & Kayit Yeri & Kayıt Tarihleri \\
\hline Full Spectrum & Karabatak - SG11 & 21 Temmuz 2017 \\
\hline Atrap & Karabatak - SG11 & 21 Temmuz 2017 \\
\hline Manuel & Toparlar - SG12 & 21 Temmuz 2017 \\
\hline Ağ & Toparlar-SG12 & 21 Temmuz 2017 \\
\hline Manuel & Kersele - SG17 & 22 Temmuz 2017 \\
\hline A $\breve{g}$ & Kersele - SG17 & 22 Temmuz 2017 \\
\hline Full Spectrum & Kavakaras1 - SG5 & 22 Temmuz 2017 \\
\hline Manuel & Toparlar - Kazanc1 Mesire Yeri & 23 Temmuz 2017 \\
\hline Ağ & Toparlar - Kazanc1 Mesire Yeri & 23 Temmuz 2017 \\
\hline Manuel & Karabatak - SG11 & 15 Eylül 2017 \\
\hline A $\breve{g}$ & Karabatak - SG11 & 15 Eylül 2017 \\
\hline Full Spectrum & Karabatak - SG11 & 15 Eylül 2017 \\
\hline Atrap & Karabatak - SG11 & 15 Eylül 2017 \\
\hline Manuel & Kersele - SG17 & 16 Eylül 2017 \\
\hline $\mathrm{Ag}$ & Kersele - SG17 & 16 Eylül 2017 \\
\hline Full Spectrum & Kersele-SG17 & 16 Eylül 2017 \\
\hline Atrap & Kersele - SG17 & 16 Eylül 2017 \\
\hline Full Spectrum & K1zılyaka-Çörüş & 17 Eylül 2017 \\
\hline Full Spectrum & Karabatak - SG11 & 18 Ocak 2018 \\
\hline Full Spectrum & Kersele - SG17 & 19 Ocak 2018 \\
\hline Full Spectrum & Kavakaras1 - SG5 & 20 Ocak 2018 \\
\hline Full Spectrum & Kavakaras1 - SG5 & 30 Mart 2018 \\
\hline Full Spectrum & Kavakaras1 - SG5 & 31 Mart 2018 \\
\hline Full Spectrum & Karabatak - SG11 & 7-21 Temmuz 2018 \\
\hline Full Spectrum & Şehir merkezi (Flora Hotel) & 19 Temmuz 2018 \\
\hline Full Spectrum & Kavakaras1 - SG5 & 27-30 Ağustos 2018 \\
\hline Full Spectrum & Karabatak - SG11 & 28 Eylül - 1 Ekim 2018 \\
\hline Full Spectrum & Karabatak - SG11 & $16-25$ Ekim 2018 \\
\hline Full Spectrum & Toparlar - SG12 & 5-7 Aralık 2018 \\
\hline Full Spectrum & Kavakaras1 - SG5 & $18-20$ Ocak 2019 \\
\hline Full Spectrum & Hamitköy - SG15 & $3-19$ Şubat 2019 \\
\hline
\end{tabular}


maya çalışılmıştır. Bu türlerin teşhisleri yapılarak (Dietz ve ark., 2009; Albayrak, 2000; Benda ve Horáček, 1998) yakalandıkları alanın koordinat ve ekolojik özellikleri kaydedilmiştir. Yakalanan can11 örneklerde başka bir işlem yapılmadan yakalandıkları habitatlarda serbest bırakılmışlardır.

Dolayısıyla, dedektörlerin yanı sıra sis a $\breve{g}$, a $\breve{g}$, atrap gibi materyallerle de arazi çalışmaları desteklenmiş ve tüm bu gözlemlere ait kayıtların özeti Tablo 1'de sunulmuştur.

Arazi çalışmaları hakkında diğer bilgiler: İzleme, dedektörler ve ağla yakalama çalışmaları Temmuz 2017-Temmuz 2019 dönem aralığında yarasaların aktif olduğu zamanlarda yapılmıştır. Bu çalışmalar gece ve gündüz olmak üzere iki ayrı zaman diliminde gerçekleştirilmiştir.

Gece arazi çalışmaları: Örneklemeler orman alanının tümünü temsil edecek şekilde ve orman meşcere haritalarına uygun olarak yapılmıştır. Öncelikli olarak alandaki yarasa varlığı ses kayıt cihazları, orman içine kurulan ağlar yardımı ile yakalanarak teşhis edilmeye çalışılmıştır.

Gündüz arazi çalışmaları: Orman içinde ve yakınlarında yarasaların barınabileceği mağara, in, kovuk, terkedilmiş yapı, kaya yarıkları, bina çatıları ve ağaç kovukları gibi yapılar araştırılarak yarasa varlığı araştırılmıştır. Bununla birlikte, Aralık 2018 - May1s 2019 dönemine ait gündüz arazi çalışmalarında hat-transekt metodu uygulanarak Anadolu sığla ormanları içerisindeki uygun ağaç kovukları, kabuk altları, dal kırıkları, yaşlı ağaçların çatlakları, ağaçkakan delikleri, ölü ve devrilmiş ağaçların boşluklu kısımları yarasa varlığı açısından incelenerek kayıt altına alınmıştır.

\subsubsection{Yarasa kutularının kurulumu}

Çalışmamızda dünya genelinde başlangıç araştırmaları için en yaygın olarak kullanılan standart yarasa kutuları tercih edilmiştir. Bu kutular ise birbirinden odacık (göz) sayısı itibariyle ayrılmakta olup genellikle tek, iki ve dört gözlü kutular tercih edilmektedir (Brittingham ve Williams, 2000).

Şekil 2'de gösterildiği gibi, odalı yarasa kutuları en az $40 \mathrm{~cm}$ genişliğinde ve $10 \mathrm{~cm}$ uzunluğunda bir gövdeye ve yaklaşık $10 \mathrm{~cm}$ uzunluğunda bir iniş pistine (iniş-kalkış çıkıntısı) sahip olmalı, sıcak bölgeler için havalandırma delikleri bulundurulmalı, odaların her biri yaklaşık $2 \mathrm{~cm}$ en ve $2,5 \mathrm{~cm}$ derinlikteki yataklara sahip olmalı, kavrama yüzeylerinde $0,5 \mathrm{~cm}$ ile $1,5 \mathrm{~cm}$ aralıklarla kesilmiş 1zgaralar-oluklar bulundurmalıdır (Craig, 2015).

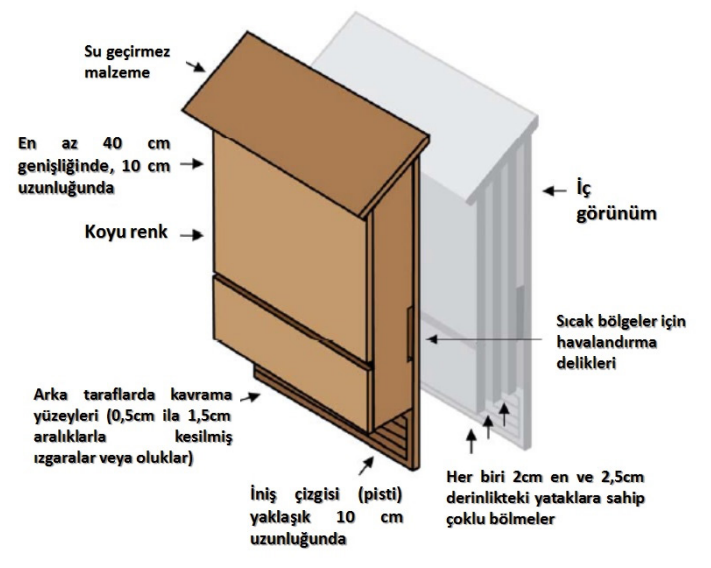

Şekil 2. Bir yarasa kutusunun temel özellikleri (Craig, 2015) Figure 2. Fundemental properties of a bat box (Craig, 2015)

Çalışmamızda teknik özellikleri yukarıda özetlenmiş ve şematize edilmiş yarasa kutuları tercih edilmiştir. 18 adet yarasa kutusunun (3 adedi büyük-tek odalı, 15 adedi küçük-iki odalı) kurulumu standart yarasa kutusunun yapımından hemen sonra 19 Temmuz 2018 tarihinde gerçekleştirilmiştir. Yarasa kutuları, orman içinde farklı özellikte habitatlar dikkate alınarak yerden en az 3 m yükseklikte ağaç gövdelerine asılmıştır. Bahsi geçen bu 18 yarasa kutusu 10 farklı sığla ormanı parçasına alan büyüklükleri dikkate alınarak eşit biçimde dağıtılmıştır (Şekil 3).

Yarasa kutularının kurulumu sonrasında kutular Kasım-Aralık 2018, Şubat 2019, Mayıs 2019 ve Temmuz 2019 dönemlerinde kontrol edilerek yarasa türlerinin kutuyu kullanım durumları gebelik, yavrulama, çiftleşme ve hibernasyona geçiş, kışlama vb. aktivasyon durumları açısından kontrol edilmiştir.

\subsubsection{Ofis çalışması}

Arazi çalışmaları sonucu tespit edilen yarasa bilgileri gün, saat, tür ad1, türün korunma statüsü, tespit şekli (ses kaydı, doğrudan gözlem), tespit edildiği koordinat ve habitat bilgisi, tespit edilen noktada ve alanda görülen tehditler ve faaliyetler gibi bilgiler Excel formatında hazırlanan bir forma girilmiştir.

Arazi çalışmasının yapıldığı koordinat noktaları ve güzergâh verileri bilgisayar ortamında Google Earth programı ile dijital haritalara işlenmiştir. Batcorder cihazı vasitasiyla kaydedilen ses dosyalarının analizi için lisanslı bcAdmin, batIdent ve bcAnalyze 2 analiz programları kullanılmıştır. İlgili veriler Apple Mac Book OSX 10.10.1 dizüstü bilgisayarda analiz edilmiş ve kaydedilmiştir. Gece hat boyunca Batbox Baton cihazı ile yapılan çalış- 
malarda elde edilen .wav formatındaki ses dosyalarının Windows İşletim Sistemi’ne sahip bilgisayara kaydedilerek üç boyutlu analizi (süre, sıklık, yoğunluk) yapılmış ve tür teşhisleri ise BatScan 9 ve BatExplorer 1.11.4 programları aracılığıyla gerçekleştirilmiştir.

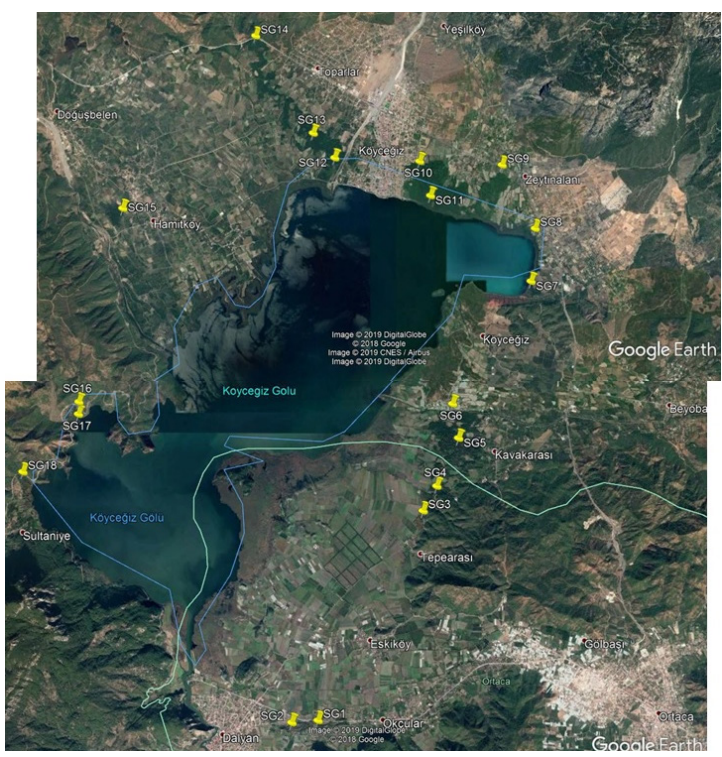

Şekil 3. Çalışma alanına yerleştirilen yarasa kutularına ait yer bulduru haritas 1

Figure 3. Location map of the bat boxes that have been placed to the study area

Elde edilen analiz sonuçlarının tür teşhislerinde verilen doğruluk yüzdelerinin küresel ölçekte yapılan çalışmalarda da görüldüğü gibi (Rydell ve ark., 2002) net sonuçları vermediği bilindiğinden ses dosyalarının analiz sonuçları Türkiye'nin farklı bölgelerinde yapılan ses kaydı ve analizlerden de yararlanılarak (Yorulmaz ve Yetkin, 2016) grafiklere aktarılmıştır. Yapılan tüm matematiksel hesaplamalar, şekil ve grafik çizimleri için Microsoft Office Excel 2013 programı kullanılmıştır.

$\mathrm{Bu}$ çalışma sonucunda elde edilen bilgiler çalışma sahasını gösteren harita üzerine işlenmiştir. Bu bilgilerden hareketle çalışma sahası içinde kaç yarasa türü yaşadığı, bu yarasaların ormanı hangi dönemlerde ve hangi amaçla kullandığı, ormanın meşcere durumu ile yarasa varlığ 1 ve aktivitesi arasındaki ilişkisi, ormandaki ormancılık ve insan faaliyetlerinin yarasalar üzerine etkileri gibi değerlendirmeler yapılmaya çalışılmıştır.

\section{Bulgular}

\subsection{Dedektör verileri}

67 günlük yarasa dedektörü çalıştırılmasına bağlı olarak manuel ve full spektrum kayıtları birlik- te ele alındığında toplamda 1978 adet ses kaydı alınmıştır. Böylece orman içinde faaliyet gösteren yarasalar ve faaliyet sıklıkları hakkında bilgi toplanmıştır. Ses kayıt analiz programına girilmiş döküm versiyonunda yer alan kayıtlarda Pipistrelloid olarak gruplanan ve karakteristik ses aralığ1 40-65 kHz arasında yer alan türlere ait geçiş sayısı 1000 ile ilk siradadır. Bu aralık 5 farklı türe (Pipistrellus pipistrellus-359, P. kuhlii-8, P. nathusi-52, P.pygmeus-8, Miniopterus schreibersii-50) işaret etmektedir. Geçis sayısı bakımından 9 geçiş ile ikinci sırada Nyctaloid grup olarak sınıflandırılan türlerden Nyctalus $s p$. yer almaktadir. Son grup olaraksa Myotis sp. 5 geçiş ile gözlenmektedir. Geriye kalan 31 adet ses kaydı ise tanımlanamamıştır (Şekil 4).

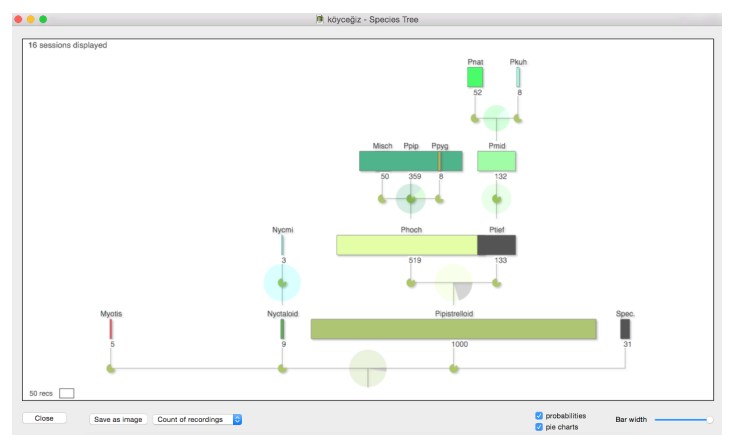

Şekil 4. Dedektör verilerine ait tür ağacı

Figure 4. Species tree of detector data

Full Spektrum Dedektör verilerinden kaydedilen 7 türün çalışma istasyonları ve zamana göre frekansları (sıklık) incelendiğinde kayıt alınan hemen hemen tüm istasyonlarda hemen hemen her dönem Pipistrellus pipistrellus-cüce yarasanın aktivitesi en s1k/yoğun olan tür olduğu gözlenmekte olup en yoğun sıklık verisinin Kavakarası istasyonundan Ağustos 2018 döneminde alındığı anlaşılmaktadır (Şekil 5).

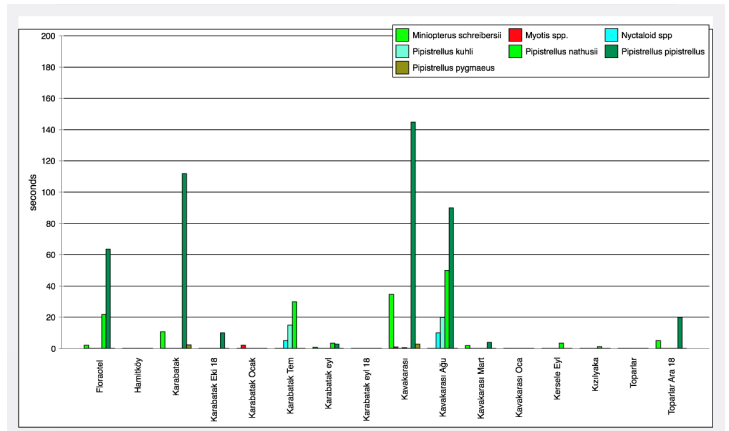

Şekil 5. Dedektör verilerinin çalışma istasyonlarına göre tür dağılımı

Figure 5. Species distribution of detector data by the study areas 
Elde edilen tüm dedektör verileri saatlik dilimlere göre incelendiğinde Anadolu sığla ormanlarında gecelik aktivitelerin en pik yaptığ 1 aktif dönemler açısından güneşin batmasına çok yakın alacakaranlıkta başlayarak arttığ 1 ilk evre, 22:00-00:00 arası gece yarısı kuşağı olarak ikinci evre ve en yoğun hareketliliğin gözlendiği 03:00-05:00 arası üçüncü evre şeklinde bir aktivite dağılım periyodu göze çarpmaktadır (Şekil 6).

Elde edilen tüm dedektör verileri yıl içinde mevsimlere göre irdelendiğinde yaz mevsiminde en yoğun aktivitelerin sergilendiği (beslenme) sonbaharda bir düşüşün yaşandığı (beslenme-kışa hazırlık) ve kış döneminde ise az da olsa düzenli bir aktivitenin olduğu (kışlama) gözlenmektedir (Şekil 7).

Full spektrum dedektörlerin yanı sıra Tablo 1'de tarih ve lokasyon bilgileri sunulan çalışma alanı içinde ve yakın çevresinde manuel yarasa dedektörü ile yapılan arazi çalışmalarında farklı hatlar boyunca yapılan izleme çalışmalarında da çeşitli yarasa kayıtları yapılmıştır. Yarasa izlemesinin yapıldığ 1 her gece yarasa aktivitesini görebilmek için gün batımının hemen ardından başlayan ve 1-2 saat süren manuel taramaların ardından bu taramaya ek olarak 23:00-00:00 saatleri arasında ek bir manuel tarama yapılarak aktivite gözlenmeye çalışılmıştır.

Manuel tarama sonucunda yoğun olarak Pipistrelloid yarasa grubu türlerine, daha az yoğunlukta da Hypsugo savi ve Nyctaloid türlere ait seslere rastlanmıştır.

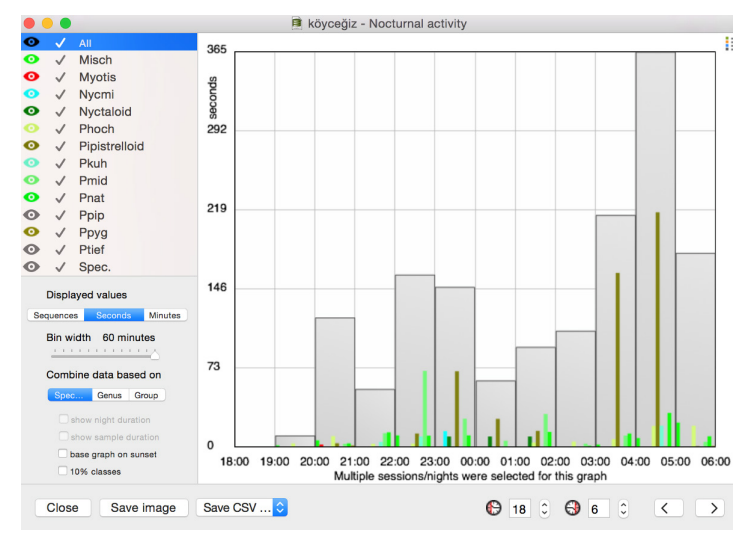

Şekil 6. Dedektör verilerinden elde edilen tür kayıtlarının günlük aktivite özelliklerine göre saatlik dağılım grafiği.

Figure 6. Hourly distribution graph of species records obtained from detector data by daily activity characteristics

\subsection{Doğrudan gözlemler}

Doğrudan gözlemler çalışma alanı içerisinde ve yakın çevresinde devamlılık arz eden habitatlarda,
Temmuz 2017-Temmuz 2019 tarihleri arasında yarasaların aktif olduğu dönemlerde yapılmıştır. Bu çalışmalar gece ve gündüz olmak üzere iki ayrı zaman diliminde gerçekleştirilmiştir.

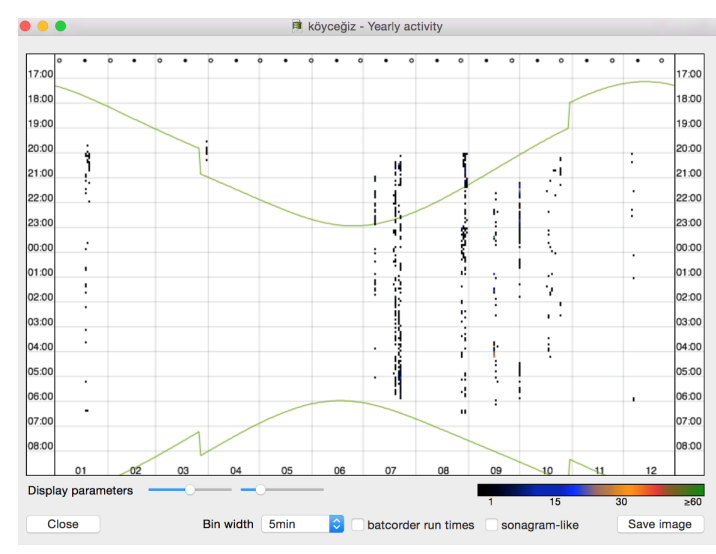

Şekil 7. Dedektör verilerinden elde edilen tür kayıtlarının yıllık aktivite özelliklerine göre saatlik dağılım grafiğ i

Figure 7. Hourly distribution graph of species records obtained from detector data by annual activity characteristics

Gece arazi çalışmaları: Ses kayıt cihazlarının yerleştirildiği noktaların yakın çevresinde orman içinde çıplak gözle yapılan gözlemlerin yanı sıra alanda kurulan ağlar, sis ağları ve atraplar yardımı ile yakalanarak teşhis edilmeye çalışılmıştır. Ancak bu materyaller ile herhangi bir veri elde edilememiştir.

Gündüz arazi çalışmaları: Orman içinde ve yakınlarında yarasaların barınabileceği mağara, in, kovuk, terkedilmiş yapı, kaya yarıkları, bina çatıları ve ağaç kovukları gibi yapılar araştırılarak yarasa varlığı araştırılmıştır.

Tüm bu yöntemlerin 1şığında Myotis daubentonii, Pipistrellus kuhlii, Pipistrellus pipistrellus, Pipistrellus pygmaeus, Plecotus macrobullaris, Rhinlophus ferrumequinum türleri olmak üzere 6 yarasa türünün Anadolu sığla ormanları içerisinde yaşadığ1 doğrudan tespit ve teşhis edilmiştir (Şekil 8).

\subsection{Yarasa kutularına ait veriler}

18 Temmuz 2018 tarihinde 30 hektar ile 250 hektar büyüklükleri arasında değişen 10 farklı sığla ormanı parçasına yerleştirilen 18 adet yarasa kutusu, yerleştirildiği tarihten itibaren Kasım-Aralık 2018, Şubat 2019, Mayıs 2019 ve Temmuz 2019 dönemleri arasında kontrol edilmiştir. Yapılan kontroller neticesinde Pipistrellus sp., Pipistrellus pipistrellus - cüce yarasa, Hypsugo savii - Savi'nin cüce yarasası türleri bu kutular içerisinde doğrudan tespit ve teşhis edilmiştir (Şekil 9). 

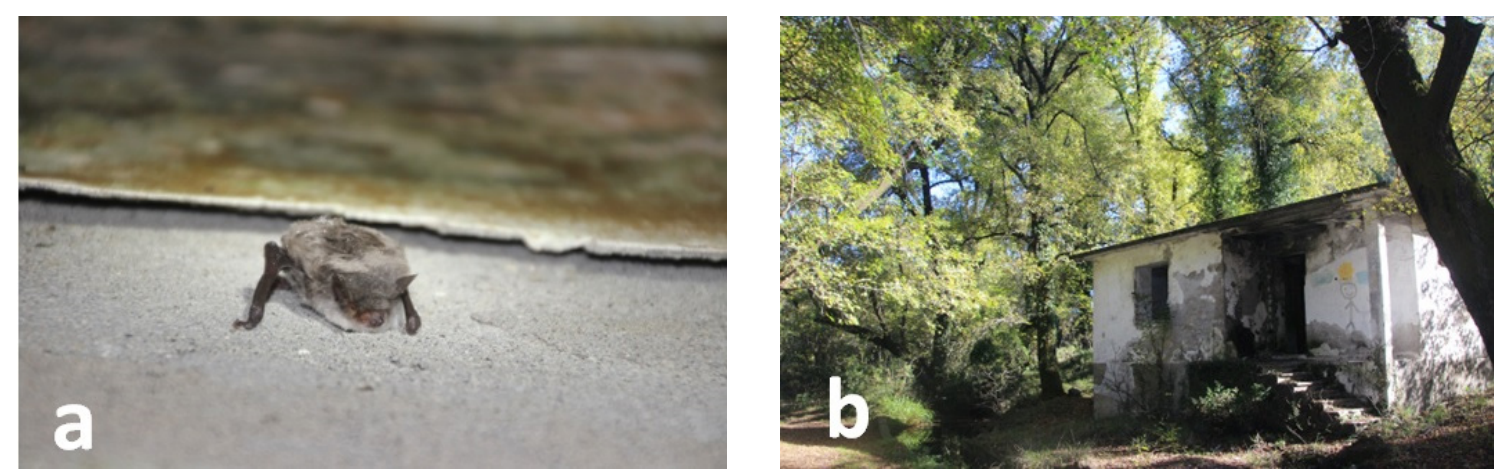

Şekil 8. Farekulaklı su yarasası (Myotis daubentonii) (a) ve sığla ormanı içerisinde tespit edildiği harabe bina (b) Figure 8. Daubenton's myotis (Myotis daubentonii) (a) and the ruin building in the Anatolian sweetgum forest (b)

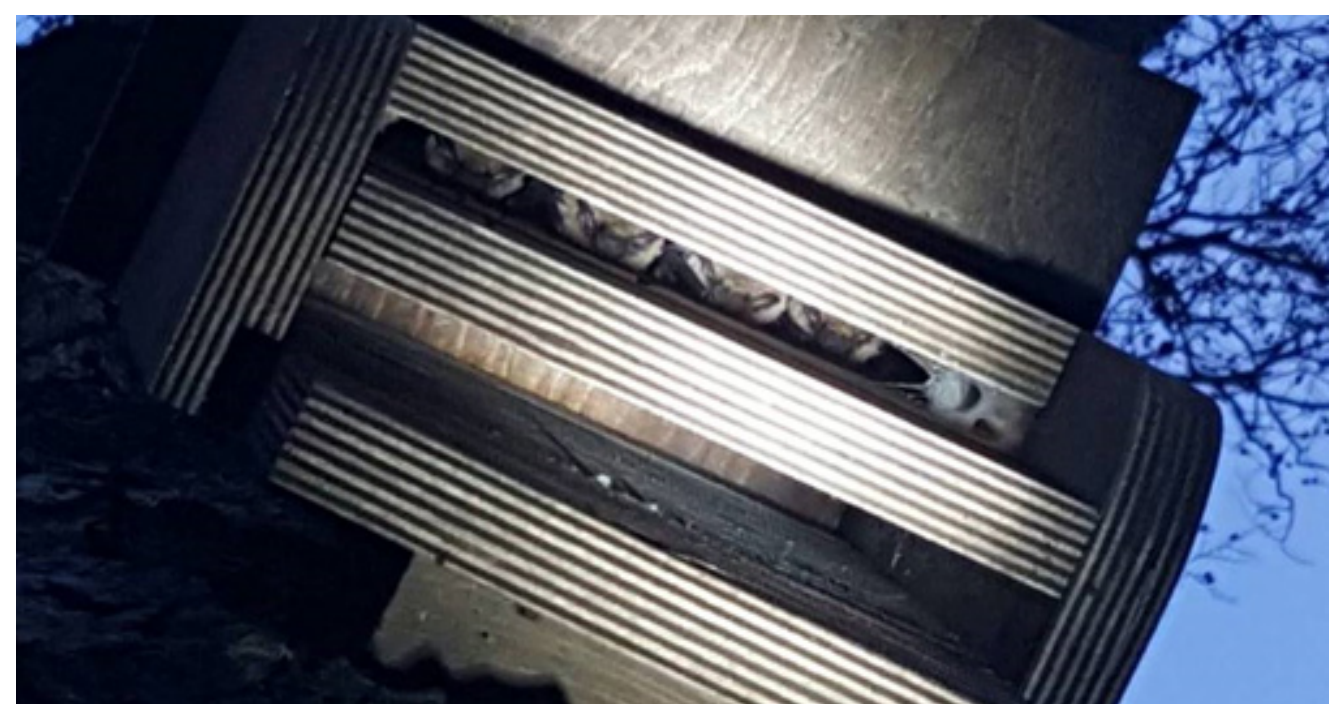

Şekil 9. Yarasa kutularını (yuvalarını) kullanmaya başlamış cüce yarasa (Pipistrellus sp.) bireylerine ait görünüm (2 Şubat 2019. SG-12 kodlu yarasa kutusu)

Figure 9.Pipistrelle (Pipistrellus sp.) individuals that began to use the bat boxes (2 February 2019. Code of SG-12 bat box).

Verilere ait genel döküm cetveli Tablo 2'de özet olarak sunulmuştur. Bu tablo incelendiğinde yuvaların sonbahar ve kış döneminde aktif olarak kullanılmasına rağmen yaz döneminde hiç kullanılmadığı da anlaşılmaktadır (Tablo 2).

\section{Sonuç ve Tartışma}

$\mathrm{Bu}$ çalışma ile yarasaların örnek bir orman ekosistemindeki varlığ 1 ve çeşitliliği ele alınmıştır.

Bu kapsamda kalıntı (relikt) ve endemik bir orman ekosistemi özelliği gösteren ve yoğun habitat parçalanmasından dolayı genetik dar boğazın eşiğine gelmiş olan Anadolu sığla ormanları; subasar orman karakterinde olması, sürekli zemininde su barındırması, kışları 1lık yazları nemli bir mikroklima sunmasından dolayı iklim, toprak, jeoloji, hidroloji, topoğrafya ve biyolojik çeşitlilik özellikleri bakımından yarasaların habitat tercihi açısından incelemeye değer bir yapı olarak tercih edilmiştir.

Örneklem alanı olarak belirlenen Muğla ilinde Köyceğiz-Dalyan Özel Çevre Koruma Bölgesi s1nırları yer alan Anadolu sığla ormanları içerisindeki yarasa tür çeşitliliği, tür zenginliği ve aktivite yoğunluğu analiz edilmiştir.

Temmuz 2017 - Temmuz 2019 dönemleri arasını kapsayan bu çalışma süresince 30 hektar ile 250 hektar genişlikleri arasında değişen 10 farklı sığla ormanı parçasında ampirik gözlemlerde bulunulmuştur. Bunun yanı sıra ağ kurulumu, atrap kullanımı, 18 adet yarasa kutusunun (evi/yuvası) yerleştirilmesi, bir adet manuel ve iki adet full-spektrum yarasa dedektörü (toplamda 67 gün/1978 adet ses kaydı alınmıştır.) kullanımı yöntem olarak tercih edilmiştir. 
Tablo 2. Yarasa kutusu verileri

Table 2. Data of bat boxes

\begin{tabular}{|c|c|c|c|c|c|c|c|c|}
\hline Yuva No & $\begin{array}{l}\text { İlk } \\
\text { Kontrol } \\
\text { Tarihi }\end{array}$ & $\begin{array}{l}\text { Yuva Durumu - Göz- } \\
\text { lenen Türler }\end{array}$ & $\begin{array}{l}\text { İkinci } \\
\text { Kontrol } \\
\text { Tarihi }\end{array}$ & $\begin{array}{l}\text { Yuva Durumu - } \\
\text { Gözlenen Türler }\end{array}$ & $\begin{array}{l}\text { Üçüncü } \\
\text { Kontrol } \\
\text { Tarihi }\end{array}$ & $\begin{array}{l}\text { Yuva Durumu - } \\
\text { Gözlenen Türler }\end{array}$ & $\begin{array}{l}\text { Son Kon- } \\
\text { trol Tarihi }\end{array}$ & $\begin{array}{c}\text { Yuva } \\
\text { Durumu } \\
\text { - Göz- } \\
\text { lenen } \\
\text { Türler }\end{array}$ \\
\hline $\begin{array}{l}\text { SG-1 } \\
\text { (Kü̧̈ük) }\end{array}$ & $\begin{array}{c}8 \\
\text { Aralık } \\
2018\end{array}$ & $\begin{array}{l}\text { Küçük yuva, iç odada } \\
\text { (ağaç tarafi) } 1 \text { adet } \\
\text { Pipistrellus sp. }\end{array}$ & $\begin{array}{c}2 \\
\text { Subat } \\
2019\end{array}$ & $\begin{array}{l}\text { Küçük yuva, iç } \\
\text { odada (ağaç tarafı) } \\
1 \text { adet Pipistrel- } \\
\text { lus sp. }\end{array}$ & $\begin{array}{c}3 \\
\text { May1s } \\
2019\end{array}$ & $\begin{array}{l}\text { Küçük yuva, iç } \\
\text { odada (ağaç tarafi) } \\
1 \text { adet Pipistrellus } \\
\text { sp. }\end{array}$ & $\begin{array}{c}23 \\
\text { Temmuz } \\
2019\end{array}$ & BOŞ \\
\hline $\begin{array}{l}\text { SG-2 } \\
\text { (Büyük) }\end{array}$ & $\begin{array}{c}8 \\
\text { Aralik } \\
2018\end{array}$ & BOŞ & $\begin{array}{l}2 \\
\text { Şubat } \\
2019\end{array}$ & BOŞ & $\begin{array}{c}3 \\
\text { May1s } \\
2019 \\
3\end{array}$ & ${ }^{s}$ & $\begin{array}{c}23 \\
\text { Temmuz } \\
2019\end{array}$ & BOŞ \\
\hline $\begin{array}{l}\text { SG-3 } \\
\text { (Küçük) }\end{array}$ & $\begin{array}{c}8 \\
\text { Aralık } \\
2018\end{array}$ & $\begin{array}{l}1 \text { adet Pipistrellus } \\
\text { sp., dış odada boş ve } \\
\text { örümcek ağ } 1 \text { vardı } \\
\text { temizlendi, }\end{array}$ & $\begin{array}{c}2 \\
\text { Subat } \\
2019\end{array}$ & $\begin{array}{l}\text { Dış odada } 1 \text { adet } \\
\text { Pipistrellus sp. }\end{array}$ & $\begin{array}{l}\text { May1s } \\
2019\end{array}$ & $\begin{array}{l}\text { Dış odada } 1 \text { adet } \\
\text { Pipistrellus sp. }\end{array}$ & $\begin{array}{c}23 \\
\text { Temmuz } \\
2019\end{array}$ & BOŞ \\
\hline $\begin{array}{l}\text { SG-4 } \\
\text { (Küçük) }\end{array}$ & $\begin{array}{c}8 \\
\text { Aralık } \\
2018\end{array}$ & $\begin{array}{l}\text { Küçük Yuva, boş, Met- } \\
\text { ruk binada, duvardaki } \\
\text { siva çatlağı altında } 1 \\
\text { adet Myotis daubento- } \\
\text { nii tespit edildi. }\end{array}$ & $\begin{array}{c}2 \\
\text { Şubat } \\
2019\end{array}$ & $\begin{array}{l}\text { Yuva boş, Metruk } \\
\text { binada herhangi } \\
\text { bir yarasaya rast- } \\
\text { lanılmadı. }\end{array}$ & $\begin{array}{c}3 \\
\text { Mayis } \\
2019\end{array}$ & $\begin{array}{l}\text { Yuva boş, Metruk } \\
\text { binada herhangi bir } \\
\text { yarasaya rastlanıl- } \\
\text { madı. }\end{array}$ & $\begin{array}{c}23 \\
\text { Temmuz } \\
2019\end{array}$ & BOŞ \\
\hline $\begin{array}{l}\text { SG-5 } \\
\text { (Büyük) }\end{array}$ & $\begin{array}{c}8 \\
\text { Aralik } \\
2018\end{array}$ & BOŞ & $\begin{array}{l}2 \\
\text { Subat } \\
2019\end{array}$ & BOŞ & $\begin{array}{c}3 \\
\text { May1s } \\
2019\end{array}$ & BOŞ & $\begin{array}{c}23 \\
\text { Temmuz } \\
2019\end{array}$ & BOŞ \\
\hline $\begin{array}{l}\text { SG-6 } \\
\text { (Küçük) }\end{array}$ & $\begin{array}{c}8 \\
\text { Aralik } \\
2018\end{array}$ & $\begin{array}{l}3 \text { yarasa var. İç odada } \\
1 \text { adet Hypsugo savii, } \\
\text { diş odada } 2 \text { adet Pipis- } \\
\text { trellus sp.var. }\end{array}$ & $\begin{array}{c}2 \\
\text { Subat } \\
2019\end{array}$ & $\begin{array}{l}\text { İç odada Hypsugo } \\
\text { savii, Diş odada } \\
\text { Pipistrellus sp. }\end{array}$ & $\begin{array}{c}3 \\
\text { May1s } \\
2019\end{array}$ & $\begin{array}{l}\text { İç odada Hypsugo } \\
\text { savii, Diş odada } \\
\text { Pipistrellus sp. }\end{array}$ & $\begin{array}{c}23 \\
\text { Temmuz } \\
2019\end{array}$ & BOŞ \\
\hline $\begin{array}{l}\text { SG-7 } \\
\text { (Küçük) }\end{array}$ & $\begin{array}{l}8 \text { Aralık } \\
2018\end{array}$ & $\mathrm{BOŞ}$ & $\begin{array}{c}2 \\
\text { Şubat } \\
2019\end{array}$ & $\begin{array}{l}2 \text { yarasa. İç ve diş } \\
\text { odada ler adet } \\
\text { Pipistrellus sp. }\end{array}$ & $\begin{array}{c}3 \\
\text { May1s } \\
2019\end{array}$ & $\begin{array}{l}2 \text { yarasa. İç ve diş } \\
\text { odada ler adet } \\
\text { Pipistrellus sp. }\end{array}$ & $\begin{array}{l}23 \text { Tem- } \\
\text { muz } 2019\end{array}$ & BOŞ \\
\hline $\begin{array}{l}\text { SG-8 } \\
\text { (Küçük) }\end{array}$ & $\begin{array}{c}8 \\
\text { Aralık } \\
2018\end{array}$ & $\begin{array}{l}2 \text { yarasa var, her bir } \\
\text { odada birer tane Pipis- } \\
\text { trellus sp. }\end{array}$ & $\begin{array}{l}2 \\
\text { Şubat } \\
2019\end{array}$ & $\begin{array}{l}2 \text { yarasa var, her } \\
\text { bir odada birer } \\
\text { tane Pipistrellus } \\
\text { sp. }\end{array}$ & $\begin{array}{c}3 \\
\text { May1s } \\
2019\end{array}$ & $\begin{array}{l}2 \text { yarasa var, her } \\
\text { bir odada birer tane } \\
\text { Pipistrellus } s p .\end{array}$ & $\begin{array}{c}23 \\
\text { Temmuz } \\
2019\end{array}$ & BOŞ \\
\hline $\begin{array}{l}\text { SG-9 } \\
\text { (Küçük) }\end{array}$ & $\begin{array}{c}8 \\
\text { Aralik } \\
2018\end{array}$ & BOŞ & $\begin{array}{l}2 \\
\text { Şubat } \\
2019\end{array}$ & $s p$ & $\begin{array}{c}3 \\
\text { May1s } \\
2019\end{array}$ & BOŞ & $\begin{array}{c}23 \\
\text { Temmuz } \\
2019\end{array}$ & BOŞ \\
\hline $\begin{array}{l}\text { SG-10 } \\
\text { (Kü̧̈ük) }\end{array}$ & $\begin{array}{c}8 \\
\text { Aralik } \\
2018\end{array}$ & BOŞ & $\begin{array}{l}2 \\
\text { Şubat } \\
2019\end{array}$ & BOŞ & $\begin{array}{c}3 \\
\text { May1s } \\
2019\end{array}$ & BOŞ & $\begin{array}{c}23 \\
\text { Temmuz } \\
2019\end{array}$ & BOŞ \\
\hline $\begin{array}{l}\text { SG-11 } \\
\text { (Küu̧ük) }\end{array}$ & $\begin{array}{c}8 \\
\text { Aralık } \\
2018\end{array}$ & BOŞ & $\begin{array}{l}2 \\
\text { Şubat } \\
2019\end{array}$ & $\begin{array}{l}\text { İç odada } 2 \text { adet } \\
\text { Pipistrellus pipis- } \\
\text { trellus } \\
\text { Küçük yuva } 4 \text { adet }\end{array}$ & $\begin{array}{c}3 \\
\text { May1s } \\
2019 \\
3\end{array}$ & $\begin{array}{l}\text { İç odada (ağaç } \\
\text { tarafi) } 2 \text { adet Pipis- } \\
\text { trellus pipistrellus }\end{array}$ & $\begin{array}{c}23 \\
\text { Temmuz } \\
2019\end{array}$ & BOŞ \\
\hline $\begin{array}{l}\text { SG-12 } \\
\text { (Kü̧̈ük) }\end{array}$ & $\begin{array}{c}17 \\
\text { Kasim } \\
2018\end{array}$ & Pipistrellus sp. & $\begin{array}{c}2 \\
\text { Subat } \\
2019\end{array}$ & $\begin{array}{l}\text { Pipistrellus } s p \text {. dış } \\
\text { odada yan yana. } \\
\text { 2'si bu senenin } \\
\text { yavrusu. }\end{array}$ & $\begin{array}{l}\text { Mayis } \\
2019\end{array}$ & $\begin{array}{l}\text { Küçük yuva } 4 \text { adet } \\
\text { Pipistrellus } s p . \text { dış } \\
\text { odada yan yana. }\end{array}$ & $\begin{array}{c}23 \\
\text { Temmuz } \\
2019\end{array}$ & BOŞ \\
\hline $\begin{array}{l}\text { SG-13 } \\
\text { (Büyük) }\end{array}$ & $\begin{array}{c}9 \\
\text { Aralık } \\
2018\end{array}$ & BOŞ & $\begin{array}{c}2 \\
\text { Şubat } \\
2019\end{array}$ & BOŞ & $\begin{array}{c}3 \\
\text { May1s } \\
2019\end{array}$ & BOŞ & $\begin{array}{c}23 \\
\text { Temmuz } \\
2019\end{array}$ & BOŞ \\
\hline $\begin{array}{l}\text { SG-14 } \\
\text { (Küu̧ük) }\end{array}$ & $\begin{array}{c}9 \\
\text { Aralık } \\
2018\end{array}$ & BOŞ & $\begin{array}{l}3 \\
\text { Subat } \\
2019\end{array}$ & BOŞ & $\begin{array}{c}4 \\
\text { May1s } \\
2019\end{array}$ & BOŞ & $\begin{array}{c}23 \\
\text { Temmuz } \\
2019\end{array}$ & BOŞ \\
\hline $\begin{array}{l}\text { SG-15 } \\
\text { (Küçük) }\end{array}$ & $\begin{array}{c}9 \\
\text { Aralik } \\
2018\end{array}$ & BOŞ & $\begin{array}{c}3 \\
\text { Subat } \\
2019\end{array}$ & BOŞ & $\begin{array}{c}4 \\
\text { May1s } \\
2019\end{array}$ & BOŞ & $\begin{array}{c}23 \\
\text { Temmuz } \\
2019\end{array}$ & BOŞ \\
\hline $\begin{array}{l}\text { SG-16 } \\
\text { (Küçük) }\end{array}$ & $\begin{array}{c}9 \\
\text { Aralık } \\
2018\end{array}$ & BOŞ & $\begin{array}{l}3 \\
\text { Subat } \\
2019\end{array}$ & BOŞ & $\begin{array}{c}4 \\
\text { Mayls } \\
2019\end{array}$ & BOŞ & $\begin{array}{c}23 \\
\text { Temmuz } \\
2019\end{array}$ & BOŞ \\
\hline $\begin{array}{l}\text { SG-17 } \\
\text { (Küçük) }\end{array}$ & $\begin{array}{c}9 \\
\text { Aralık } \\
2018\end{array}$ & BOŞ & $\begin{array}{c}3 \\
\text { Subat } \\
2019\end{array}$ & BOŞ & $\begin{array}{c}4 \\
\text { May1s } \\
2019\end{array}$ & BOŞ & $\begin{array}{c}23 \\
\text { Temmuz } \\
2019\end{array}$ & BOŞ \\
\hline $\begin{array}{l}\text { SG-18 } \\
\text { (Küęük) }\end{array}$ & $\begin{array}{c}9 \\
\text { Aralik } \\
2018 \\
\end{array}$ & BOŞ & $\begin{array}{c}3 \\
\text { Subat } \\
2019 \\
\end{array}$ & BOŞ & $\begin{array}{c}4 \\
\text { May1s } \\
2019 \\
\end{array}$ & BOŞ & $\begin{array}{c}23 \\
\text { Temmuz } \\
2019\end{array}$ & BOŞ \\
\hline
\end{tabular}


Araştırma sonucunda bu orman ekosisteminde toplamda 11 farklı yarasa türü kaydedilmiştir. Teşhis edilen tüm yarasa türlerine ait küresel ve ulusal yayılış durumları, ulusal ve uluslararası korunma statüleri, tüneme tercihleri ve tespit-kayıt şekilleri Tablo 3'te özetlenmiştir.

Tablo 3. Anadolu sığla ormanlarında kaydedilen yarasa faunası (Yorulmaz ve Arslan, 2016'dan geliștirilerek). Table 3. Bat fauna recorded in Anatolian sweetgum forests (developed from Yorulmaz ve Arslan, 2016).

\begin{tabular}{|c|c|c|c|c|c|c|c|c|c|c|c|}
\hline \multirow[t]{2}{*}{ Türler } & \multirow[t]{2}{*}{ Türkçe adı } & \multicolumn{2}{|c|}{$\begin{array}{l}\text { Küresel } \\
\text { ölçekte }\end{array}$} & \multicolumn{3}{|c|}{ Ulusal ölçekte } & \multirow[t]{2}{*}{ Bern } & \multirow[t]{2}{*}{ Cites } & \multirow[t]{2}{*}{ IUCN } & \multirow[t]{2}{*}{ TOB } & \multirow[t]{2}{*}{ Kayit } \\
\hline & & $\mathrm{L}$ & B G & $\mathrm{L}$ & $\mathrm{B}$ & $\mathrm{G}$ & & & & & \\
\hline Rhinolophus ferrumequinum & $\begin{array}{l}\text { Büyük nalbu- } \\
\text { runlu yarasa }\end{array}$ & & $\mathrm{X}$ & & & $\mathrm{X}$ & II & & $\mathrm{LC}$ & KA & $\mathrm{D}$ \\
\hline Myotis daubentonii & Su yarasası & & $\mathrm{X}$ & $X$ & & & II & & $\mathrm{LC}$ & KA & $\mathrm{D}$ \\
\hline Myotis emerginatus & Çentikli yarasa & & $\mathrm{X}$ & $\mathrm{X}$ & & & II & & $\mathrm{LC}$ & KA & M \\
\hline Pipistrellus pipistrellus & Cüce yarasa & & $X$ & & & $X$ & III & & $\mathrm{LC}$ & & $\begin{array}{c}\mathrm{FS}, \\
\mathrm{M}, \mathrm{D}, \\
\mathrm{YK}\end{array}$ \\
\hline Pipistrellus pygmaeus & $\begin{array}{l}\text { Akdeniz cüce } \\
\text { yarasası }\end{array}$ & & $\mathrm{X}$ & $\mathrm{X}$ & & & II & & $\mathrm{LC}$ & & FS, D \\
\hline Pipistrellus kuhlii & $\begin{array}{l}\text { Beyaz şeritli } \\
\text { yarasa }\end{array}$ & & $X$ & $X$ & & & II & & $\mathrm{LC}$ & KA & FS, D \\
\hline Pipistrellus nathusii & $\begin{array}{l}\text { Pürtük derili } \\
\text { yarasa }\end{array}$ & & $X$ & $\mathrm{X}$ & & & II & & $\mathrm{LC}$ & KA & FS \\
\hline Hypsugo savii & $\begin{array}{l}\text { Savinin cüce } \\
\text { yarasası }\end{array}$ & & $\mathrm{X}$ & $\mathrm{X}$ & & & II & & $\mathrm{LC}$ & KA & $\begin{array}{l}\text { M, } \\
\mathrm{YK}\end{array}$ \\
\hline Plecotus macrobullaris & $\begin{array}{l}\text { Dağ uzun ku- } \\
\text { laklı yarasası }\end{array}$ & & $\mathrm{X}$ & $X$ & & & II & & $\mathrm{LC}$ & & $\mathrm{D}$ \\
\hline Miniopterus schreibersii & $\begin{array}{l}\text { Uzun kanatlı } \\
\text { yarasa }\end{array}$ & & $\mathrm{X}$ & & & $\mathrm{X}$ & II & & NT & KA & FS \\
\hline Myotis sp. & $\begin{array}{l}\text { Akşameı Yara- } \\
\text { salar }\end{array}$ & & & & & & & & & & FS \\
\hline Nyctalus sp. & $\begin{array}{l}\text { Farekulakl1 } \\
\text { Yarasalar }\end{array}$ & & & & & & & & & & FS \\
\hline
\end{tabular}

L: Lokal, B: Bölgesel, G: Geniș

BERN: Avrupa’nın Yaban Hayatı ve Yaşama Ortamlarını Koruma Sözleşmesi. EK-II / Kesin Koruma Altındaki Hayvan Türleri, EK-III / Koruma Altındaki Hayvan Türleri.

CITES: Nesli Tehlikede Olan Yabani Hayvan Ve Bitki Türlerinin Uluslararası Ticaretine İlișkin Sözleșme (Cites Sözleșmesi)

IUCN Red List: Tehdit Altındaki Türlerin Kırmızı Listesi. LC: Least Concerned (Asgari Endişe Düzeyi), NT: Near Threatened (Tehdit Altına Girmeye Yakın).

TOB: KA: Tarım ve Orman Bakanlığınca Koruma Altında.

Kayıt: D-Doğrudan, FS-Full spektrum, M-Manuel dedektör, YK-Yarasa kutusu.

Tüm bu çalışmalar hep birlikte ele alındığında manuel dedektör verileri analiz edildiğinde 3 yarasa türü, full spektrum dedektör verileri analiz edildiğinde 7 tür (2'si cins düzeyinde), yarasa kutular1na ait veriler analiz edildiğinde 3 tür ve doğrudan gözlem verileri analiz edildiğinde 6 türün tespit ve teşhisi sonucunda Anadolu sığla ormanlarında ve yakın çevresindeki bağlantılı habitatlarda toplamda 13 yarasa türünün (2'si cins düzeyinde) varlığ 1 kaydedilmiştir. Bu türlerden Myotis daubentonii, Myotis emarginatus, Pipistrellus nathusii, Pipistrellus pygmaeus, Plecotus macrobullaris bölge için ilk kez kaydedilmiştir.

Yarasa ve orman ilişkileri bazında yapılan çalışmalarda gerek ormancılık gerekse diğer insan aktivitelerinin yarasaları olumsuz etkilediği vurgulanmaktadır (Lacki ve ark., 2007; Yorulmaz ve ark., 2016). Bu faaliyetler yoğun ve plansız ağaç kesimleri, madencilik faaliyetleri, orman yangınlar1, böceklerle mücadele ve rüzgâr türbinleri ana başlıkları altında toplanabilir (Lacki ve ark., 2007). Anadolu sığla ormanları özelinde doğal etmenler taban suyunun tuzlanması, zararlı böcekler, zararlı mantarlar ve istilacı bitki türleri olarak, insan etmenli sorunlar ise baraj ve HES projeleri, plansız ağaç kesimleri, kaçak sığla yağı üretimi, tarımsal alan açma amaçlı yaşanan işgaller, bu işgallerin oluşabilmesi için yapılan kesme, yakma, drenaj kanalı açma gibi problemler olarak özetlenebilir. Şüphesiz Anadolu sığla ormanlarında yaşayan 
yarasaların da yukarıda siralanan problemlerden doğrudan veya dolaylı olarak olumsuz etkilenmesi kaçınılmaz olacaktır. Bunu önlemek için en acil ve keskin koruma tedbirleri, öncelikli olarak habitatların doğrudan ve geri dönüşsüz biçimde ortadan kalkmasına yol açan baraj ve HES projelerini kontrol altında tutmaya ve tarımsal alan açma amaçlı yaşanan işgallere bağlı orman varlığ 1 kaybını önlemeye yönelik olmalıdır. Bahsi geçen diğer dolaylı etkileri minimize edebilme ve yarasa popülasyonlarının korunmasına katkıda bulunma konusundaki tedbirler ise üç farklı aşamada ele alınmalıdır (Yorulmaz ve ark., 2018; Weller, 2008).

a-Tüneme alanlarl: Yarasalar genel olarak karanlik, nispeten nemli ve $11 \mathrm{k}\left(15-30{ }^{\circ} \mathrm{C}\right)$ alanları tünemek için kullanırlar. Bu alanlar mağaralar, terkedilmiş yapılar, ağaç kovukları ve kaya yarıkları gibi alanlardır. Anadolu sığla ormanları içerisinde de bu tarz yapılar mevcut olup bunlar uzmanlar eşliğinde Muğla Orman Bölge Müdürlüğü, Muğla İl Çevre ve Şehircilik Müdürlüğü (Tabiat Varlıklarını Koruma Şube Müdürlükleri), Köyceğiz Doğa Koruma ve Milli Parklar Şefliği yetkilileri ile tespit edilerek mümkün olduğunca korunmalıdır. Sığla ormanı alanında ve yakınlarında bulunacak mağaraların mutlak koruma altına alınması gerekmektedir.

Bu mağaraların özellikle giriş kısımlarının ormanc1lık faaliyetlerinden etkilenmemesi için giriş k1sımlarına $100 \mathrm{~m}$ mesafede bir alanın koruma zonu olarak belirlenmesi önerilmektedir. Ayrıca orman içinde tüneme özelliği taşıyan ağaçların belirlenmesi ve korunması önerilmektedir. Bununla birlikte bu türlerin tespit edildiği ormanlardaki ağaç türlerinin karışımı da korunmalıdır.

b-Beslenme alanlarl: Yarasalar beslenmek için genellikle yüksek bitki örtüsüne sahip alanları ve su kıyılarını kullanırlar. Sığla ormanı ekosisteminde ise orman içi açıklıklar ve çalılıklar, orman içi yollar, orman içi dereler, bataklıklar, ormanın göl ile birleştiği orman kenarındaki sazlıklar gibi farklı habitatlar öncelikli beslenme alanlarıdır. $\mathrm{Bu}$ alanlarda ormancılık faaliyetleri, alanın mevcut örüntüsünü değiştirmeyecek düzeyde yapılmalıdır. Yarasaların ses kayıtlarının alındığı yani beslenme davranışı sergiledikleri sığla ormanı habitatlarında, bireysel ağaç kesiminden çok fazla etkilenmemekle birlikte daha çok büyük alanları içeren tıraşlama benzeri faaliyetlerden olumsuz etkilenecektir. $\mathrm{Bu}$ sebeple ses kayıtlarının veya emarelerin tespit edildiği alanlarda, habitat özelliğinin tamamen değişimine yol açmayacak küçük çaplı faaliyetlere izleme ve etki azaltıcı tedbirlerin alınması şartıyla izin verilebileceği kanaati hasıl olmaktadır.

c-Biyolojik döngüleri: Yarasalar Ekim-Nisan ayları arasında tüneme noktalarında kış uykusuna yatarlar. Bahsi geçen bu alanlar bazen ağaç kovukları, ağaçkakan yuvaları, kabuklu ağaçların kabuk altlar1, ölü ve devrik ağaçların çatlakları vb. olabilmektedir. $\mathrm{Bu}$ dönemde yapılacak ağaç kesimlerinde yarasaların yaşayabileceği ağaçlarda hayvan varlığına dikkat edilmelidir. Yarasalar, Haziran - Temmuz ayları arasında ise yavrulama ve yavru bakımı aşamasındadır. $\mathrm{Bu}$ dönemlerde de yapılacak ormancılık faaliyetlerinde özellikle kesimi yapılacak ağaçların kovuk ve kabuk durumu kontrol edilerek hayvan varlığı dikkate alınmalıdır. Ağustos-Eylül aylarında ise yarasalar çiftleşme aşamasındadır ve bu dönemde yoğun göç hareketleri ve beslenme faaliyetleri sergilemektedirler. Bu dönemlerde yarasaların ses kayıtlarının alındığı yani beslenmeleri için önemli alanlarda keskin habitat değişsimine yol açacak faaliyetler yapılmamalıdır. Nitekim çalışma alanında yapılan dedektör taramaları, doğrudan gözlemler ve yarasa kutularından elde edilen gözlem sonuçları da Anadolu sığla ormanları özelinde bu literatür bilgilerini teyit etmektedir.

Bu çalışma ile Türkiye'de ilk kez bir orman ekosisteminde sistemli biçimde yarasa ekolojisine yönelik araştırmalar gerçekleştirilmiştir. Elde edilen bu sonuçlar, orman amenajman planlarına entegre edilebilme potansiyeli taşımakla beraber Anadolu sığla ormanlarının korunmasına yönelik de yol gösterici bilgiler sunmaktadır. Dahası çalışma kapsamında elde edilen çeşitli bulgulardan biyoçeşitlilik, yaban hayatı, sulak alanlar ve diğer doğa koruma alanlarında faaliyet gösteren ilgili kurum ve kuruluşların yürüttüğü çalışmalardan faydalanma potansiyeli de bulunmaktadır.

Öte yandan, ilgili çalışma süresinin ve metodoloji kapsamında kullanılan materyallerin, cihazların vs. arttırılması sonucunda, bölgenin yarasa ekolojisi özelinde yaban hayatı özelliklerini anlamak ve buna göre koruma eylem planları ve izleme planları geliştirebilme noktasında daha sağlıklı ve uzun erimli kestirimlere ulaşılabileceği de mutlak surette ifade edilmelidir.

Sonuç olarak bu çalışma ile Anadolu sığla ormanlarındaki yarasalar hakkında öncül bilgiler derlenmiş ve öneriler sunulmuştur. Öte yandan, Türkiye ormanlarının yarasalar açısından önemine ilişkin daha detaylı çalışmalara ihtiyaç duyulduğu da açıktır. Türkiye'nin orman ve yarasa varlığı düşünülerek gelecekte insan faaliyetlerinin orman alanlarını daha fazla etkileyecek olması gerçeği de dikkate alındığında, bu konudaki araştırma ve koruma çalışmalarına ihtiyacın artacağı da göz önünde tutulmalidir.

$\mathrm{Bu}$ çalışmanın literatüre ve koruma biyolojisi alanına katkıları şu şekilde özetlenebilir: 
Türkiye'de orman ekosistemi içinde yaşayan ve bugüne kadar dikkate alınmamış türler olan yarasalar hakkında orman alanlarını nasıl kullandıkları, hangi türlerin hangi dönemlerde orman alanlarını tercih etmiş oldukları konusunda tespitler yapılmıştır. Orman Genel Müdürlüğünün son yıllarda yürütmekte olduğu “Orman amenajman planlarına biyolojik çeşitliliğin entegrasyonu” çalışmalarında kullanılmak üzere yarasalar ve orman ilişkileri hakkında bilgiler elde edilmiştir. Orman içinde ağaç zararlısı olarak bilinen böcek türleri ile o böcekler üzerinden beslenen yarasalar arasındaki ilişkilerin ortaya konmasında öncül bilgiler elde edilmiştir. Bu çalışma, yarasa kutularının ormanda yaşayan yarasalar tarafindan kullanılma durumları ortaya konulduğundan biyolojik mücadele çalışmaları için örnek bir uygulama özelliği taşımaktadır. Türkiye yarasa varlığına Anadolu sığla ormanlarından ve Güneybatı Anadolu Bölgesi'nden ilk kayıtlar verilmiştir. Bu çalışmadan elde edilen veriler ile Tersiyer dönemli relikt ve Doğu Akdeniz endemiği olan Anadolu sığla ormanlarının korunmasına katkıda bulunulmuştur.

\section{Teşekkürler}

$\mathrm{Bu}$ araştırma makalesi, sorumlu yazarın Çankırı Karatekin Üniversitesi Fen Bilimleri Enstitüsünde makale ile aynı ismi taşıyan yüksek lisans tez çalışmasından derlenmiştir. Bu çalışma, The Rufford Foundation (www.rufford.org) tarafindan (Proje No: 26671-B) kısmen desteklenmiştir. Verilerin sağlanmasında ve alan çalışmalarının sağlıklı bir şekilde yürütülmesinde sağladıkları desteklerinden ötürü Köyceğiz Orman İşletme Müdürü Hakan Zeybek'e ve Köyceğiz Orman İşletme Müdürlüğünün ilgili tüm çalışanlarına teşekkür ederiz.

\section{Kaynaklar}

Alan, M., Kaya, Z., 2003. Oriental Sweet Gum (Liquidambar orientalis Mill.). EUFORGEN Technical Guidelines.

Albayrak, İ., 2000. Yarasalar, Eli kanatlı memeli. Yeşil Atlas, Coğrafya ve Keşif Dergisi, Doğan Burda Rizzoli Dergi Yayıncılık ve Pazarlama A.Ş., İstanbul, 3: 69-73 (2000).

Albayrak, İ., Aşan, N. 1999. Distributional Status of the Bats from Turkey. Communications of the Faculty of Sciences of the University of Ankara, Series C,17(1/2): 59-68.

Anthony, E.L.P., Kunz, T.H. 1977. Feeding strategies of the little brown bat, Myotis lucifugus, in southern New Hampshire. Ecology, 58: 775-786.

Aşan, N., Baydemir N., 2014. Bat Fauna of Turkey and Northern Cyprus: Species Diversity, Anthropogenic Roost Disturbance and Conservation Status. Journal of International Environmental Application and Science.

\section{9: 590-596, 2014.}

Baran, I., Kumlutaş, Y., Kaska, Y., Türkozan, O., 1994. Research on the Amphibia, Reptilia and Mammalia Species of the Köyceğiz- Dalyan Special Protected Area. Doğa-Turk. J. Zool. 18:203-219.

Benda, P., Horáček, I., 1998. Bats (Mammalia: Chiroptera) of the Eastern Mediterranean. Part 1. Review of distribution and taxonomy of bats in Turkey, Acta Soc. Zool. Bohem., 62 (4): 255-313.

Bogdanowicz, W., Rajan, K. E., Arasamuthu, A. S., Marimuthu, G., Dabrowski, M., 2014. Baby sitting and aspects of non-maternal infant support in the carnivorous bat Megaderma lyra. XIIIth European Bat Research Symposium, 1- 5 th September 2014, Siberik, Crotia.

Brigham, R.M., Barclay, R.M.R., Psyllakis, J.M., Sleep, D.J.H., Lowrey, K.T., 2002. Guano traps as a means of assessing habitat use by foraging bats. Northwest Naturalist 85:15-18.

Brittingham, M.C., Williams, L.M., 2000. Bat boxes as alternative roosts for displaced bat maternity colonies. Wildlife Society Bulletin 28:197-207.

Correia, R., Faneca, C., Vieira, J. M., Bastos, C., Mascarenhas, M., Costa, H., \& Pereira, M. J. R., 2013. Bat Monitoring System for Wind Farms. IFAC Proceedings Volumes, 46(28), 110-115.

Craig, J., 2015. Building Homes for Bats: A Guide for Bat Houses in BC. https://www.bcbats.ca/index.php/bathouses (Erişim tarihi: 5 Mart 2019).

Dietz, C., Helversen O.v., Nill, D., 2009. Bats of Britain, Europe \& Northwest Africa. ISBN: 9781408105313, A\&C Black Publishing, 400p.

Ekim, T., Koyuncu, M., Vural, M., Duman, H., Aytaç, Z., Adıgüzel N., 2000. Türkiye Bitkileri Kırmızı Listesi, (Red Data Book of Turkish Plants (Pteridophyta and Angiospermae)). Türkiye Tabiatını Koruma Derneği ve Van 100. Yıl Üniversitesi Yayını, 246 Syf. Ankara.

Evelyn, M.J., Stiles D.A., Young R.A., 2004. Conservation of bats in suburban landscapes: roost selection by Myotis yumanensis in a residential area in California. Biological Conservation 1 15:463-473

IUCN, 2020. Redlist of threatened species, version 2019-3. $<$ www. IUCNRedlist. org> (Erişim tarihi: 1 Ocak 2020).

Jackson, 2015. The Leaflet of Bats \& Trees www.bats. org.uk/data/files/publications/Bats_Trees.pdf (Erişim tarihi: 2 Ocak 2018)

Kavak, S., Wilson, B., 2018. Liquidambar orientalis. The IUCN Red List of Threatened Species 2018: e.T62556A42326468. http://dx.doi.org/10.2305/IUCN. UK.2018-1.RLTS.T62556A42326468.en. (Erişim tarihi: 10 Ağustos 2019)

Kerth, G., Wiesmann, K., König, B., 2001. Day roost selection in female Bechstein's bats (Myotis bechsteini): a field experiment to determine the influence of roost temperature. Oecologia 126:1-9. 
Korner-Nievergelt, F., Brinkmann, R., Niermann, I., Behr, O., 2013. Estimating bat and bird mortality occurring at wind energy turbines from covariates and carcass searches using mixture models. PloS one, 8(7), e67997.

Kurt, L., 2008. Anadolu Sığla Ağacı (Günlük Ağacı) Biyolojik Çeşitlilik Raporu. Özel Çevre Koruma Kurumu Başkanlığı, Ankara.

Lacki, M. J., Hayes J. P., Kurta, A. (eds.)., 2007. Bats In Forests: Conservation And Management. Johns Hopkins University Press, Baltimore, Maryland, 329 pp. ISBN: 0-8018-8499-3.

Lunney, D., Barker, J., Priddel, D., O'Connell, M., 1988. Roost selection by Gould's long-eared bat, Nyctophilus gouldi Tomes (Chiroptera: Vespertilionidae), in logged forest on the south coast of New South Wales. Aust. Wildl. Res. 15: 375-384.

Merrit, J.F., 2010. The biology of small mammals. The Johns Hopkins University Press. Baltimore, 1-312, 2010.

Neuweiler, G., 1990. Auditory adaptations for prey capture in echolocating bats. Physiological Reviews, Vol. 70. No.3, July 1990. Pages 615-637. Printed in USA.

Obrist, M. K., Boesch, R., Flückiger, P.F., 2004. "Variability in echolocation call design of 26 Swiss bat species: consequences, limits and options for automated field identification with a synergetic pattern recognition approach." Mammalia 68(4): 307 - 321.

O'Shea, T. J., Bogan, M. A., 2003. Introduction. Pp. 1-7 in O'Shea, T. J. and M. A. Bogan (eds.), Monitoring trends in bat populations of the United States and territories: problems and prospects. U.S. Geological Survey, Information and Technology Report 2003-003, 274 pp.

Özkil, A., Ürker, O., Zeydanl1, U., 2017. Art in Sweetgum Forest. Nature Conservation Centre, 161 Pages, Dumat Ofset, ISBN: 978-605-82749-0-7. Ankara-TURKEY.

Parsons, S., Jones, G., 2000. "Acoustic identification of twelve species of echolocating bat by discriminant function analysis and artificial neural networks." Journal of Experimental Biology 203(17): 2641-2656.

Richardson, E., P., 2011. Bats. Natural History Museum Life Sciences. London Natural History Museum, London, 1-128.

Russo, D., Jones, G., 2002. "Identification of twentytwo bat species (Mammalia: Chiroptera) from Italy by analysis of time-expanded recordings of echolocation calls." Journal of Zoology London 258(1): 91-103.

Rydell, J., Arita, H. T., Granados, J., 2002. "Acoustic identification of insectivourous bats (order Chiroptera) of Yucatan, Mexico." Journal of Zoology London 257: 27-36.
Speakman, JR, Thomas, DW, 2003. Physiological ecology and energetics of bats. In: Kunz TH, Fenton MB (eds) Bat ecology. University of Chicago Press, Chicago, pp 430-492.

Taylor, P.J., 2000. Bats of Southern Africa: Guide to biology, identification, and conservation. University of Kwazulu Natal Press, South Africa.

Tuttle, M. D., M. Kiser, Kiser, S., 2004. The Bat House Builder's Handbook: Second Edition. Bat Conservation International, Austin, Texas. http://www.batcon.org/ pdfs/BHBuildersHdbk13_Online.pdf (Erişim tarihi: 5 Mart 2019).

Ürker, O., Çobanoğlu, N., 2017. Çevre Etiği Bağlamında Anadolu Sığla Ormanları. 204 Syf. ISBN: 978-3-659-941993. LAP Lambert Academic Publishing, Germany, 2017.

Ürker, O., Lise, Y., 2018. Doğa Korumada Yeni Bir Kavram Olan Hassas Orman Ekosistemlerinin Anadolu Siğla Ormanları Üzerinden İncelenmesi. Anadolu Orman Araştırmaları Dergisi, 4 (2018) 1-10.

Vonhof, M.J., Whitehead, H., Fenton, M.B., 2004. Analysis of Spix's disk-winged bat association patterns and roosting home ranges reveal a novel social structure among bats. Animal Behaviour 68:507-521.

Waldien, D.L., Hayes, J.P,. 2001. Activity areas of female long-eared Myotis in coniferous forests in western Oregon. Northwest Science 75: 307-314.

Weller, T.J., 2008. Bölgesel çok-türlü bir koruma planının etkinliğini değerlendirmek için doluluk tahmininin kullanılması: Pasifik Kuzeybatısındaki yarasalar. Biological Conservation 141: 2279-2289.

Yorulmaz T, Arslan N, 2016. Türkiye Yarasalarının (Mammalia: Chiroptera) Son Durumu ve Ulusal Korunma Statüleri İçin Öneriler (Poster Sunum) 23. Ulusal Biyoloji Kongresi, 5-9 Eylül 2016, Gaziantep. șẸp?

Yorulmaz, T., Yetkin, D., 2016. Türkiye'deki Bazı Yarasa (Mammalia: Chiroptera) Türlerinin Sonogram Analizleri. 23. Ulusal Biyoloji Kongresi. Gaziantep Üniversitesi. Özet kitabı. $218 \mathrm{~s}$.

Yorulmaz T, Yetkin D, Arslan N, Erdoğan A. 2016. Türkiye Yarasalarında Aktivite Yoğunluğunun Sıcaklık, Rüzgar Hızı, Yükseklik ve Bitki Örtüsü ile ilişkisinin Belirlenmesi 23. Ulusal Biyoloji Kongresi, 5-9 Eylül 2016, Gaziantep. is:

Yorulmaz, T., Ürker, O., Özmen, R., 2018. Yarasa ve orman ilişkisi üzerine bir değerlendirme. (Orman Genel Müdürlüğ̈̈) Ormancılık Araştırma Dergisi, 2018, 5:1, 31-43. 